\title{
LEI FICHA LIMPA ESTADUAL E LIMITES CONSTITUCIONAIS DE SUA PRODUÇÃO LEGISLATIVA: ANÁLISE DA "INACESSIBILIDADE A CARGOS EM COMISSÃO" POR CONDENADOS POR IMPROBIDADE ADMINISTRATIVA SEM TRÂNSITO EM JULGADO - O CASO DA LEI CATARINENSE
}

\section{Ruy Samuel Espíndola}

Resumo: $O$ ensaio discute aspectos de constitucionalidade de leis ficha limpa estaduais que impedem acesso a cargos públicos em comissão de cidadãos que estão enquadrados nas mesmas hipóteses da Lei Complementar nacional 135/10. Historia parte do movimento "ficha limpa" e sua midiática repercussão no cenário nacional e estadual. Expõe sobre a necessidade de se preservarem direitos fundamentais processuais e direitos fundamentais políticos violados pela lei catarinense n. 15.381/10. Toma como exemplo crítico essa lei, para alertar outros Estados ou Municípios da Federação a evitarem as inconstitucionalidades presentes em sua narrativa. Discute a iniciativa do Executivo na matéria e a competência da União em matéria de improbidade. Demonstra as conexões existentes entre os valores constitucionais da presunção de inocência e inelegibilidade; irretroação gravosa das leis novas; segurança jurídica, proporcionali-

1 Professor de Direito Constitucional da Escola Superior de Magistratura de Santa Catarina e Professor de Direito Constitucional Eleitoral e Recursos Eleitorais na Pós-Graduação em Direito Eleitoral do CESULBRA - Mestre em Direito Público pela UFSC - Autor do livro "Conceito de Princípios Constitucionais" - Conferencista Internacional - Secretário de Comissão Especial do Conselho Federal da OAB (a em prol da emenda constitucional de iniciativa popular) - Sócio gerente da Espíndola \& Valgas, Advogados Associados, com sede em Florianópolis/SC - Advogado militante perante o TSE e STF. E-mail: ruysamuel@hotmail.com 
dade e ampla defesa nos temas ligados as condenações colegiadas de improbidade administrativa; o conceito de pena e seus reflexos para a inelegibilidade e inacessibilidade a cargos públicos. Evidencia as duas vertentes de aborgagem que se embatem em torno do tema: a moralista e a constitucionalista.

Palavras-chave: Ficha limpa. Lei estadual. Vedação para provimento em cargos em comissão. Constitucionalidade. Iniciativa reservada. Competências da União. Direitos Fundamentais Políticos. Direitos Fundamentais Processuais. Moralistas e Constitucionalistas. Preservação das Instituições Democráticas.

\section{INTRODUÇÃO}

O ideário "ficha limpa" há cinco anos vem ganhando força na cena jurídica e política brasileira. Desde seu aparecimento, em voto vencido dado pelo Ministro Carlos Ayres Britto no TSE (e acompanhado pelo então Ministro José Delgado), caso Eurico Miranda ${ }^{2}$, cujo julgamento findou em 20.09.2006, passou-se a discutir, com grande intensidade, o valor moral de candidaturas, os pressupostos éticos e a idoneidade para postulações políticas eletivas.

Depois disso, adveio a Arguição de Descumprimento de Preceito Fundamental n. 144, movida pela Associação da Magistratura Brasileira - AMB, que tencionava fazer prevalecer,

2 "RECURSO ORDINÁRIO no 1069 - Rio De Janeiro/RJ Acórdão de 20/09/2006 Relator(a) Min. MARCELO HENRIQUES RIBEIRO DE OLIVEIRA Ementa: Eleições 2006. Registro de candidato. Deputado federal. Inelegibilidade. Idoneidade moral. Art. $14, \S 9^{\circ}$, da Constituição Federal. 1. O art. $14, \S 9^{\circ}$, da Constituição não é auto-aplicável (Súmula $n^{\circ} 13$ do Tribunal Superior Eleitoral). 2. Na ausência de lei complementar estabelecendo os casos em que a vida pregressa do candidato implicará inelegibilidade, não pode o julgador, sem se substituir ao legislador, defini-los. Recurso provido para deferir o registro. Decisão: O Tribunal, por maioria, proveu o Recurso, na forma do voto do Relator."

O Ministro Carlos Britto, oficiante como juiz vogal, restou vencido. Em suas teses, defendeu a auto-aplicabilidade do artigo, tendo em conta, entre outros argumentos, o conceito de vida pregressa e a etimologia da palavra candidato, que designa, segundo seu dito, "cândido", "puro", "honesto". 
por decisão com efeito vinculante, a idéia de autoaplicação do artigo $14, \S 9 \circ$ (já enaltecida no voto vencido do Ministro Britto, em 2006, no TSE), cujo resultado, indeferitório, ocorreu em 20.08.20083.

3 "ADPF 144, Relator: Min. CELSO DE MELLO, Tribunal Pleno, julgado em 06/08/2008, DJe-035 DIVULG 25-02-2010 PUBLIC 26-02-2010 RTJ VOL-00215PP-00031 - E M E N T A: ARGÜIÇÃO DE DESCUMPRIMENTO DE PRECEITO FUNDAMENTAL - (....) MÉRITO: RELAÇÃO ENTRE PROCESSOS JUDICIAIS, SEM QUE NELES HAJA CONDENAÇÃO IRRECORRÍVEL, E O EXERCÍCIO, PELO CIDADÃO, DA CAPACIDADE ELEITORAL PASSIVA - REGISTRO DE CANDIDATO CONTRA QUEM FORAM INSTAURADOS PROCEDIMENTOS JUDICIAIS, NOTADAMENTE AQUELES DE NATUREZA CRIMINAL, EM CUJO ÂMBITO AINDA NÃO EXISTA SENTENÇA CONDENATÓRIA COM TRÂNSITO EM JULGADO - IMPOSSIBILIDADE CONSTITUCIONAL DE DEFINIR-SE, COMO CAUSA DE INELEGIBILIDADE, A MERA INSTAURAÇÃO, CONTRA O CANDIDATO, DE PROCEDIMENTOS JUDICIAIS, QUANDO INOCORRENTE CONDENAÇÃO CRIMINAL TRANSITADA EM JULGADO - PROBIDADE ADMINISTRATIVA, MORALIDADE PARA O EXERCÍCIO DO MANDATO ELETIVO, "VITAANTEACTA" E PRESUNÇÃO CONSTITUCIONAL DE INOCÊNCIA - SUSPENSÃO DE DIREITOS POLÍTICOS E IMPRESCINDIBILIDADE, PARA ESSE EFEITO, DO TRÂNSITO EM JULGADO DA CONDENAÇÃO CRIMINAL (CF, ART. 15, III) - REAÇÃO, NO PONTO, DA CONSTITUIÇÃO DEMOCRÁTICA DE 1988 À ORDEM AUTORITÁRIA QUE PREVALECEU SOB O REGIME MILITAR - CARÁTER AUTOCRÁTICO DA CLÁUSULA DE INELEGIBILIDADE FUNDADA NA LEI COMPLEMENTAR № 5/70 (ART. 10, I, “N”), QUE TORNAVA INELEGÍVEL QUALQUER RÉU CONTRA QUEM FOSSE RECEBIDA DENÚNCIA POR SUPOSTA PRÁTICA DE DETERMINADOS ILÍCITOS PENAIS - DERROGAÇÃO DESSA CLÁUSULA PELO PRÓPRIO REGIME MILITAR (LEI COMPLEMENTAR № 42/82), QUE PASSOU A EXIGIR, PARA FINS DE INELEGIBILIDADE DO CANDIDATO, A EXISTÊNCIA, CONTRA ELE, DE CONDENAÇÃO PENAL POR DETERMINADOS DELITOS ENTENDIMENTO DO SUPREMO TRIBUNAL FEDERAL SOBRE O ALCANCE DA LC No 42/82: NECESSIDADE DE QUE SE ACHASSE CONFIGURADO O TRÂNSITO EM JULGADO DA CONDENAÇÃO (RE 99.069/BA, REL. MIN. OSCAR CORREAA) - PRESUNÇÃO CONSTITUCIONAL DE INOCÊNCIA: UM DIREITO FUNDAMENTAL QUE ASSISTE A QUALQUER PESSOA - EVOLUÇÃO HISTÓRICA E REGIME JURÍDICO DO PRINCÍPIO DO ESTADO DE INOCÊNCIA - O TRATAMENTO DISPENSADO À PRESUNÇÃO DE INOCÊNCIA PELAS DECLARAÇÕES INTERNACIONAIS DE DIREITOS E LIBERDADES FUNDAMENTAIS, TANTO AS DE CARÁTER REGIONAL QUANTO AS DE NATUREZA GLOBAL - O PROCESSO PENAL COMO DOMÍNIO MAIS EXPRESSIVO DE INCIDÊNCIA DA PRESUNÇÃO CONSTITUCIONAL DE INOCÊNCIA - EFICÁCIA IRRADIANTE DA PRESUNÇÃO DE INOCÊNCIA - POSSIBILIDADE DE EXTENSÃO DESSE PRINCÍPIO AO ÂMBITO DO PROCESSO ELEITORAL - HIPÓTESES DE INELEGIBILIDADE - ENUMERAÇÃO EM ÂMBITO CONSTITUCIONAL (CF, ART. 14, §§ $4^{\circ}$ $A 8^{\circ}$ ) - RECONHECIMENTO, NO ENTANTO, DA FACULDADE DE O CONGRESSO NACIONAL, EM SEDE LEGAL, DEFINIR "OUTROS CASOS DE INELEGIBILIDADE" - NECESSÁRIA OBSERVÂNCIA, EM TAL SITUAÇÃO, DA RESERVA CONSTITUCIONAL DE LEI COMPLEMENTAR (CF, ART. 14, § $9^{\circ}$ ) - IMPOSSIBILIDADE, CONTUDO, DE A LEI COMPLEMENTAR, MESMO COM APOIO NO $\S 9^{\circ}$ DO ART. 14 DA CONSTITUIČÃO, TRANSGREDIR A PRESUNÇÃO CONSTITU- 
O movimento chamado ficha limpa culminou em setembro de 2009, com a apresentação de projeto de lei de iniciativa popular levado ao Congresso Nacional, promulgado pela Presidência da República em 04.06.2010, como a Lei Complementar n. 135, de 04 de junho de 2010.

Logo depois de sua entrada em vigor, o TSE, mobilizado pelo movimento e seu estardalhaço midiático, surpreendentemente, editou a equívoca resposta a Consulta $n^{\circ} 1.120-26 / D F$ (formulada pelo Senador Artur Virgílio do PSDB), Relatada pelo então Ministro do TSE Hamilton Carvalhido, que, além de outras conclusões questionadas na justiça eleitoral e no STF, entendeu que a LC 135/10 era aplicável ao pleito de 2010 e a fatos jurídicos passados, não constituindo pena a inelegibilidade e não havendo incidência retroativa de seus dispositivos nas hipóteses de inelegibilidade nela versadas.

O STF só pode solver a grande insegurança jurídica ocasionada pelo TSE em 10.06 .2010 , em 23.03.2011, por maioria (6 x 5), com o acórdão proferido no caso Leonídas Rebouças, RE 633.703, Relator Ministro Gilmar Mendes, ao dizer, sem sombra de dúvidas, que essa lei não poderia ser aplicada às eleições de 2010, por força da regra da anualidade, insculpida no artigo 16 da Constituição da República ${ }^{4}$.

\footnotetext{
CIONAL DE INOCÊNCIA, QUE SE QUALIFICA COMO VALOR FUNDAMENTAL, VERDADEIRO "CORNERSTONE" EM QUE SE ESTRUTURA O SISTEMA QUE A NOSSA CARTA POLÍTICA CONSAGRA EM RESPEITO AO REGIME DAS LIBERDADES E EM DEFESA DA PRÓPRIA PRESERVAÇÃO DA ORDEM DEMOCRÁTICA - PRIVACCÃO DA CAPACIDADE ELEITORAL PASSIVA E PROCESSOS, DE NATUREZA CIVIL, POR IMPROBIDADE ADMINISTRATIVA - NECESSIDADE, TAMBÉM EM TAL HIPÓTESE, DE CONDENACCÃO IRRECORRÍVEL - COMPATIBILIDADE DA LEI No 8.429/92 (ART. 20, "CAPUT") COM A CONSTITUIČ̃̃O FEDERAL (ART. 15, V, c/c O ART. 37, § $4^{\circ}$ )- O SIGNIFICADO POLÍTICO E O VALOR JURÍDICO DA EXIGÊNCIA DA COISA JULGADA (...) - ARGÜIÇÃO DE DESCUMPRIMENTO DE PRECEITO FUNDAMENTAL JULGADA IMPROCEDENTE, EM DECISÃO REVESTIDA DE EFEITO VINCULANTE."

4 Informativo do STF: "Por maioria de votos, o Plenário do Supremo Tribunal Federal (STF) decidiu que a Lei Complementar (LC) 135/2010, a chamada Lei da Ficha Limpa, não deve ser aplicada às eleições realizadas em 2010, por desrespeito ao artigo 16 da Constituição Federal, dispositivo que trata da anterioridade da lei eleitoral. Com essa decisão, os ministros estão autorizados a decidir individualmente casos sob sua relatoria, aplicando o artigo 16 da Constituição Federal. A decisão aconteceu no julgamento do Recurso Extraordinário (RE) 633703, que discutiu a
} 
Lembremos que o efeito do "discurso ficha limpa" foi tão impactante sobre a opinião pública e o congresso nacional, que não houve votos contrários a sua aprovação. Tanto no Senado, quanto na Câmara dos Deputados, à unanimidade, foi aprovado. E aprovado em tempo recorde, para um projeto com a seriedade e conseqüências jurídicas de suas proposições normativas, por emparedamento do Congresso pela mídia e opinião pública moldada pela primeira.

constitucionalidade da Lei Complementar 135/2010 e sua aplicação nas eleições de 2010. Por seis votos a cinco, os ministros deram provimento ao recurso de Leonídio Correa Bouças, candidato a deputado estadual em Minas Gerais que teve seu registro negado com base nessa lei. Relator O ministro Gilmar Mendes votou pela não aplicação da lei às eleições gerais do ano passado, por entender que o artigo 16 da Constituição Federal (CF) de 1988, que estabelece a anterioridade de um ano para lei que altere o processo eleitoral, é uma cláusula pétrea eleitoral que não pode ser mudada, nem mesmo por lei complementar ou emenda constitucional. Acompanhando o relator, o ministro Luiz Fux ponderou que "por melhor que seja o direito, ele não pode se sobrepor à Constituição". Ele votou no sentido da não aplicabilidade da Lei Complementar n 135/2010 às eleições de 2010, com base no princípio da anterioridade da legislação eleitoral. O ministro Dias Toffoli acompanhou o voto do relator pela não aplicação da Lei da Ficha Limpa nas Eleições 2010. Ele reiterou os mesmo argumentos apresentados anteriormente quando do julgamento de outros recursos sobre a mesma matéria. Para ele, o processo eleitoral teve início um ano antes do pleito. Em seu voto, o ministro Marco Aurélio também manteve seu entendimento anteriormente declarado, no sentido de que a lei não vale para as eleições de 2010. Segundo o ministro, o Supremo não tem culpa de o Congresso só ter editado a lei no ano das eleições, "olvidando" o disposto no artigo 16 da Constituição Federal, concluiu o ministro, votando pelo provimento do recurso. Quinto ministro a se manifestar pela inaplicabilidade da norma nas eleições de 2010, o decano da Corte, ministro Celso de Mello, disse em seu voto que qualquer lei que introduza inovações na área eleitoral, como fez a Lei Complementar 135/2010, interfere de modo direto no processo eleitoral - na medida em que viabiliza a inclusão ou exclusão de candidatos na disputa de mandatos eletivos - o que faz incidir sobre a norma o disposto no artigo 16 da Constituição. Com este argumento, entre outros, o ministro acompanhou o relator, pelo provimento do recurso. Último a votar, o presidente do Supremo Tribunal Federal (STF), ministro Cezar Peluso, reafirmou seu entendimento manifestado nos julgamentos anteriores sobre o tema, contrário à aplicação da Lei Complementar no 135/2010 às eleições do ano passado. "Minha posição é bastante conhecida", lembrou. Peluso ressaltou o anseio comum da sociedade pela probidade e pela moralização, "do qual o STF não pode deixar de participar". Para o presidente, "somente má-fé ou propósitos menos nobres podem imputar aos ministros ou à decisão do Supremo a ideia de que não estejam a favor da moralização dos costumes políticos". Observou, porém, que esse progresso ético da vida pública tem de ser feito, num Estado Democrático de Direito, a com observância estrita da Constituição. "Um tribunal constitucional que, para atender anseios legítimos do povo, o faça ao arrepio da Constituição é um tribunal em que o povo não pode ter confiança", afirmou.O ministro aplicou ao caso o artigo 16, "exaustivamente tratado", e o princípio da irretroatividade "de uma norma que implica uma sanção grave, que é a exclusão da vida pública". A medida, para Peluso, não foi adotada "sequer nas ditaduras". 
Durante a eleição de 2010, tivemos, inclusive, um candidato a Vice-Presidente ${ }^{5}$, cujo maior argumento de sua candidatura, foi o fato de ter sido o Relator, na Câmara dos Deputados, de dito projeto, e de ter contribuído para sua agilidade e aprovação no parlamento brasileiro.

O DEM, em nível nacional, assumiu a autoria ideológica parlamentar do projeto, que teve iniciativa popular, com mais de 1.600.000 assinaturas. A internet foi veículo de grande circulação de idéias em apoio ao ideário ficha limpa.

Muitos partidos e candidatos, dos mais diferentes matizes, durante o pleito de 2010, se disseram "ficha limpa", como o maior argumento para legitimar suas candidaturas - independentemente de seus projetos, passado e presente... de suas convicções políticas ou programas partidários.

Em 12.10.11, feriado nacional, milhares de pessoas reunidas em diversas Capitais do País pediram a aplicação de seus ditames às eleições de 2012 e clamaram para que o STF a declare constitucional. Pessoas ligadas ao salutar movimento contra a corrupção. Unidas pelas redes sociais, sem intermediação dos tradicionais órgãos de política em uma sociedade organizada: partidos e/ou sindicatos.

É sabido que abaixo assinado foi endereçado à Presidenta Dilma, para que nomeie um magistrado para a Suprema Corte - no lugar de Ellen Gracie, que se aposentou recentemente comprometido com o ideário "Ficha Limpa". ${ }^{6}$

Muitas questões em torno da constitucionalidade desta lei, algumas adiante tratadas, serão solvidas, quiçá ainda este ano, no STF, que deverá julgar duas ações declaratórias de constitucionalidades - uma movida pelo Conselho Federal da $\mathrm{OAB}$ (ADC n. 30), e outra pelo Partido Popular Socialista - PPS (ADC n. 29), e, ainda, uma ação direta de inconstitucionalidade

\footnotetext{
5 Índio da Costa do Brasil (DEM), vice de José Serra, PSDB.

$6 \mathrm{Na}$ seguinte fonte colhemos esta informação, acessada em 17.10.2011: http:// www.em.com.br/app/noticia/politica/2011/09/13/interna_politica,250323/abaixoassinado-pressiona-por-indicacao-de-ministro-a-favor-da-ficha-limpa-no-stf.shtml.
} 
movida pela Confederação Nacional das Profissões Liberais (ADIN n. 4578). Para todas essas ações, por conexão, o Relator é o Ministro Luiz Fux, o mesmo que desempatou a discussão, no STF, sobre a aplicação da lei ficha limpa às eleições de $2010 .{ }^{7} \mathrm{~A}$ Procuradoria Geral da República manifestou parecer favorável a constitucionalidade da lei, em todos os aspectos questionados. Em alguns Estados da federação ${ }^{8}$, o teor da lei eleitoral complementar n. 135/10 - seu discurso moralista -, estimulou iniciativas locais e mesmo municipais a fazerem lei semelhante, para impedir que pessoas, que incidissem em hipóteses semelhantes ou idênticas as da lei eleitoral, pudessem ocupar postos no poder público: cargos em comissão, empregos em comissão, funções de confiança, emprego temporário, etc.

Através de projeto de iniciativa parlamentar do Deputado Estadual Cesar Souza Júnior, DEM/SC, foi apresentada

7 A primeira Adin, a de n. 4.578, é de 30.01.11, movida pela Confederação Nacional das Profissões Liberais, pedindo o reconhecimento da inconstitucionalidade da letra "m", do artigo $2^{\circ}$, da LC $135 / 10$, por malferir a razoabilidade (extrapolaria a competência dos conselhos profissionais, que farão papel de juiz eleitoral, aplicar penas disciplinares que tenham conseqüências eleitorais cívicas) - estando, segundo a petição inicial da Confederação, "a saltar aos olhos a inconstitucionalidade". A segunda foi uma ação declaratória de constitucionalidade (ADC 29), movida pelo PPS, aforada em 19.04.11, que postula a declaração de constitucionalidade da lei, para aplicá-la a fatos e decisões ocorridas antes de sua entrada em vigor. Afirma, repetindo jargões do TSE e dos apologistas da lei: que ao dispor a Constituição da República (no artigo $14, \S 9^{\circ}$ ) de vida pregressa, moralidade para o exercício do mandato e probidade administrativa, claro que poderia e deveria retroagir a LC 135/90 para aplicação a fatos passados; depois, inelegibilidade, segundo o discurso dessa inicial, não seria pena, por tanto as garantias penais não se Ihe aplicariam, como a idéia de legalidade penal prévia, etc. Que inelegibilidade seria aferida na data do pedido de candidatura, regendo-lhe o deferimento a lei em vigor neste tempo, o tempo de pedido de candidatura. Outra razão para a constitucionalidade seria que ninguém tem o direito inato e inalienável de se candidatar. A terceira ação seria uma declaratória de constitucionalidade proposta pelo Conselho Federal da OAB federal (ADC 30), em 03.05.11, pedindo valia da aplicação retroativa, no mesmo sentido do PPS, mas com mais argumentos de causa petendi - razoabilidade e proporcionalidade justificariam a espécie. Inelegibilidade não é pena e não impõe punição; vida pregressa autorizaria aplicação ao passado, etc. Presunção de inocência não se aplicaria como impediente, por que não se trata de pena a inelegibilidade; o valor maior a tutelar, no caso da lei de inelegibilidades, é a proteção da moralidade administrativa, que é valor constitucional, e para os afetados pela LC 135/90 haveria sempre a possibilidade de se pedir a medida cautelar prevista no artigo 26-C, da atual redação da LC 64/90.

8 E. g., Piauí, Maranhão e Santa Catarina. 


\section{proposição à Assembléia Legislativa de SC, que se transformou}

na lei estadual n. 15.381, de 17.12.2010², que visa impedir que

9 LEI № 15.381, de 17 de dezembro de 2010 Procedência - Dep. Cesar Souza Júnior Natureza - PL./0262.0/2010 DO. 18.994 de 20/12/2010: "Disciplina a nomeação para cargos em comissão no âmbito dos órgãos dos Poderes Executivo, Legislativo, Judiciário e do Tribunal de Contas do Estado e adota outras providências. O GOVERNADOR DO ESTADO DE SANTA CATARINA, Faço saber a todos os habitantes deste Estado que a Assembleia Legislativa decreta e eu sanciono a seguinte Lei: Art. $1^{2}$ Fica vedada a nomeação para cargos em comissão no âmbito dos órgãos dos Poderes Executivo, Legislativo, Judiciário e do Tribunal de Contas do Estado às pessoas inseridas nas seguintes hipóteses: a) os que tenham contra sua pessoa representação julgada procedente pela Justiça Eleitoral, em decisão transitada em julgado ou proferida por órgão colegiado, em processo de apuração de abuso do poder econômico ou político, desde a decisão até o transcurso do prazo de 8 (oito) anos; b) os que forem condenados, em decisão transitada em julgado ou proferida por órgão judicial colegiado, desde a condenação até o transcurso do prazo de 8 (oito) anos após o cumprimento da pena, pelos crimes: 1 . contra a economia popular, a fé pública, a Administração Pública e o patrimônio público; 2. contra o patrimônio privado, o sistema financeiro, o mercado de capitais e os previstos na lei que regula a falência; 3 . contra o meio ambiente e a saúde pública; 4 . eleitorais, para os quais a lei comine pena privativa de liberdade; 5 . de abuso de autoridade, nos casos em que houver condenação à perda do cargo ou à inabilitação para o exercício de função pública; 6 . de lavagem ou ocultação de bens, direitos e valores; 7 . de tráfico de entorpecentes e drogas afins, racismo, tortura, terrorismo e hediondos; 8. de redução à condição análoga a de escravo; 9 . contra a vida e a dignidade sexual; e 10. praticados por organização criminosa, quadrilha ou bando; c) os que forem declarados indignos do oficialato, ou com ele incompatíveis, pelo prazo de 8 (oito) anos; d) os que tiverem suas contas relativas ao exercício de cargos ou funções públicas rejeitadas por irregularidade insanável que configure ato doloso de improbidade administrativa, e por decisão irrecorrível do órgão competente, salvo se esta houver sido suspensa ou anulada pelo Poder Judiciário, aplicando-se o disposto no inciso II do art. 71 da Constituição Federal, a todos os ordenadores de despesa, sem exclusão de mandatários que houverem agido nessa condição, desde a decisão até o transcurso do prazo de 8 (oito) anos; e) os detentores de cargo na Administração Pública direta, indireta ou fundacional, que beneficiarem a si ou a terceiros, pelo abuso do poder econômico ou político, que forem condenados em decisão transitada em julgado ou proferida por órgão judicial colegiado, desde a decisão até o transcurso do prazo de 8 (oito) anos; f) os que forem condenados, em decisão transitada em julgado ou proferida por órgão colegiado da Justiça Eleitoral, por corrupção eleitoral, por captação ilícita de sufrágio, por doação, captação ou gastos ilícitos de recursos de campanha ou por conduta vedada aos agentes públicos em campanhas eleitorais que impliquem cassação do registro ou do diploma, desde a decisão até o transcurso do prazo de 8 (oito) anos; g) os que forem condenados à suspensão dos direitos políticos, em decisão transitada em julgado ou proferida por órgão judicial colegiado, por ato doloso de improbidade administrativa que importe lesão ao patrimônio público e enriquecimento ilícito, desde a condenação ou o trânsito em julgado até o transcurso do prazo de 8 (oito) anos após o cumprimento da pena; $\mathrm{h}$ ) os que forem excluídos do exercício da profissão, por decisão sancionatória do órgão profissional competente, em decorrência de infração ético-profissional, pelo prazo de 8 (oito) anos, salvo se o ato houver sido anulado ou suspenso pelo Poder Judiciário; i) os que forem demitidos do serviço público em decorrência de processo administrativo ou judicial, pelo prazo de 8 (oito) anos, contado da decisão, salvo se o ato houver sido suspenso ou anulado pelo Poder Judiciário; j) os membros do Governo do Estado, da 
ocupem cargos em comissão no Legislativo, Executivo, Judiciário, Tribunal de Contas e Ministério Público de SC, pessoas que incidam nas mesmas hipóteses previstas na LC 135/10.

A iniciativa, sem dúvida, é politicamente correta e moralmente apetecível. Precisamos indagar, no Direito, se ela é juridicamente aceitável, ou melhor, se é constitucionalmente sustentável.

Isso porque o legislador pode muito, mas não pode tudo, em uma democracia constitucional estável, onde existe uma constituição rígida, fixadora de direitos fundamentais e da separação de poderes, que instituiu uma corte constitucional independente para interpretá-la, aplicá-la e protegê-la frente aos arroubos de maiorias circunstanciais ou de opiniões públicas majoritárias contra constitutione.

E no caso das leis estaduais ou municipais que lhe copiem a iniciativa ideológica e moralista, há mais limites legiferantes, decorrentes do sistema de direitos fundamentais, da separação de poderes e das competências federativas, do que os postos ao legislador eleitoral federal.

O objetivo deste ensaio é analisar alguns destes limites, focando nas inconstitucionalidades das leis estaduais, tomando

Assembleia Legislativa, do Tribunal de Justiça e do Tribunal de Contas do Estado, que forem aposentados compulsoriamente por decisão sancionatória, e que tenham perdido o cargo por sentença ou que tenham pedido exoneração ou aposentadoria voluntária na pendência de processo administrativo disciplinar, pelo prazo de 8 (oito) anos. Art. $2^{\circ} \mathrm{A}$ vedação prevista na alínea "b" deste artigo não se aplica aos crimes culposos e àqueles definidos em lei como de menor potencial ofensivo, nem aos crimes de ação penal privada. Art. $3^{\circ}$ Todos os atos efetuados em desobediência às vedações previstas serão considerados nulos. Art. 4ํㅡㄹ Caberá ao Governo do Estado, à Assembleia Legislativa, ao Tribunal de Justiça e ao Tribunal de Contas do Estado, de forma individualizada, a fiscalização de seus atos em obediência a presente Lei, com a possibilidade de requerer aos órgãos competentes informações e documentos que entender necessários para o cumprimento das exigências legais. Art. $5^{\circ} \mathrm{O}$ nomeado ou designado, obrigatoriamente antes da posse, terá ciência das restrições e declarará por escrito não encontrar-se inserido nas vedações do art. $1^{\circ}$ desta Lei. Art. $6^{\circ} \mathrm{O}$ Governador do Estado e os Presidentes da Assembleia Legislativa, do Tribunal de Justiça e do Tribunal de Contas do Estado, dentro do prazo de noventa dias, contados da publicação desta Lei, promoverão a exoneração dos atuais ocupantes de cargos de provimento em comissão, nas situações previstas no art. 1․ Parágrafo único. Os atos de exoneração produzirão efeitos a contar de suas respectivas publicações. Art. 7을 As denúncias de descumprimento desta Lei, deverão ser encaminhadas ao Ministério Público, que ordenará as providências cabíveis na espécie. Art. $8^{\circ}$ Esta Lei entra em vigor na data de sua publicação. Florianópolis, 17 de dezembro de 2010 LEONEL ARCÂNGELO PAVAN Governador do Estado." 
como exemplo de laboratório o caso da lei catarinense, que é emblemático. Limitando-se ao recorte do tema de condenação por improbidade, sem trânsito em julgado.

O teor da lei estadual catarinense é idêntico ao da Lei ficha limpa eleitoral. Ocupa-se em impedir que cargos em comissão, nos poderes Executivo, Legislativo, Judiciário, Ministério Público e Tribunal de Contas, em SC, sejam ocupados por pessoas que incidam nas suas hipóteses vedatórias.

Adiante tomaremos como reflexão crítica, a lei catarinense, abordando cinco aspectos que denunciam suas inconstitucionalidades formal, orgânica e material.

Assim o fazemos para alertar a comunidade jurídica e política sobre os direitos fundamentais que estão em jogo e o valor de uma Constituição que exige respeito e efetividade, sobretudo em momentos nos quais a paixão, o preconceito e a irreflexão são a tônica dos discursos midiáticos.

\section{OS PROJETOS QUE VERSEM SOBRE INACESSIBILIDADE A CARGOS PÚBLICOS DEVEM RESPEITAR A REGRA DE INICIATIVA RESERVADA DA CHEFIA DO EXECUTIVO, SOB PENA DE INCONSTITUCIONALIDADE FORMAL}

O projeto que resultou na lei ficha limpa estadual barrigaverde é inconstitucional, pois é fruto de iniciativa parlamentar, e não de iniciativa do Executivo, como exigem, para tema de provimento em cargos públicos, a Constituição Federal. Há flagrante vício de iniciativa, de origem do projeto. E assim todos os seus dispositivos, transformados na lei estadual n. 15.381/10, não tem validade. Há na espécie legislativa em crítica, o que se chama de inconstitucionalidade formal ${ }^{10}$.

$10 \mathrm{O}$ conceito de inconstitucionalidade formal, orgânica e material foram retirados das seguintes obras, que explicam seus efeitos no plano do controle de constitucionalidade: Elival da Silva Ramos. A Inconstitucionalidade das Leis. Vício e Sanção. São Paulo: Saraiva, 1994. 255 p. e Luis Roberto Barroso. O Controle de Constitucionalidade no Direito Brasileiro. São Paulo: Saraiva, 2004. 299 p. 
Para entender a inconstitucionalidade em foco, precisamos relembrar o significado jurídico de provimento: provimento é o "ato de designação de alguém para titularizar cargo público", segundo Celso Antonio Bandeira de Mello (Curso de Direito Administrativo, 27ª ed., São Paulo: Malheiros, 2010, p. 308). Para Carmem Lúcia Antunes Rocha, "provimento de cargo público é o suprimento formal da necessidade pública havida e demonstrada na sua vacância, conferindo-se a alguém a condição de titular responsável pelo desempenho das atribuições e das funções que lhe são inerentes." (Princípios constitucionais dos servidores públicos. São Paulo: Saraiva, 1999, p. 169.)

Legislar sobre provimento, então, é normatizar as regras que definem o acesso aos cargos públicos, é legislar sobre "acessibilidade" aos cargos públicos.

A regra parâmetro violada foi à constante do seguinte dispositivo constitucional que integra processo legislativo, portanto, de observância obrigatória para os Estados Membros: "Art. 61. A iniciativa das leis complementares e ordinárias cabe a qualquer membro ou Comissão da Câmara dos Deputados, do Senado Federal ou do Congresso Nacional, ao Presidente da República, ao Supremo Tribunal Federal, aos Tribunais Superiores, ao Procurador-Geral da República e aos cidadãos, na forma e nos casos previstos nesta Constituição. $\$ 11^{\circ}$ - São de iniciativa privativa do Presidente da República as leis que: (...) II - disponham sobre: (...) c) servidores públicos da União e Territórios, seu regime jurídico, provimento de cargos, estabilidade e aposentadoria; (Redação dada pela Emenda Constitucional n ${ }^{\circ}$ 18, de 1998)."

A jurisprudência do STF é pacífica em precedentes neste sentido ${ }^{11}$.

11 Vejamos: "EMENTA: AÇÃO DIRETA DE INCONSTITUCIONALIDADE. ARTS. 135, I; E 138, CAPUT E $\S 3 .^{\circ}$, DA CONSTITUIÇÃO DO ESTADO DA PARAÍBA. AUTONOMIA INSTITUCIONAL DA PROCURADORIA-GERAL DO ESTADO. REQUISITOS PARA A NOMEACÃOO DO PROCURADOR-GERAL, DO PROCURADOR-GERAL ADJUNTO E DO PROCURADOR-CORREGEDOR. (...) Os demais dispositivos, ao estabelecerem requisitos para a nomeação dos cargos de chefia da Procuradoria-Geral do Estado, limitam as prerrogativas do Chefe 
Assim, quando as leis estaduais, que disporem sobre o tema provimento - versando a inacessibilidade a cargos públicos - insuperável será a inconstitucionalidade da lei estadual ficha limpa, por regular provimento de cargos públicos em lei cuja origem adveio de projeto de iniciativa parlamentar e não de iniciativa privativa do executivo.

3 O LEGISLADOR ESTADUAL NÃO PODE INVADIR COMPETÊNCIA LEGISLATIVA DA UNIÃO FEDERAL E INOVAR DISPOSITIVOS DA LEI NACIONAL 8.429/92, ALTERANDO SEUS EFEITOS PROCESSUAIS, CONTEÚDO E EXTENSÃO DE SUAS PENAS - HAVERÁ VIOLAÇÃO AOS ARTIGOS 22, I, C/C 37, § $4^{\circ}$, DA CONSTITUIÇÃOFEDERAL-INCONSTITUCIONALIDADE ORGÂNICA - DESVALIA PARCIAL E PONTUAL DA LEI ESTADUAL CATARINENSE N. 15.381, DE 17 DE DEZEMBRO DE 2010

Quando leis estaduais ou municipais, ao modo da lei catarinense, regularem hipótese proibitiva a condenados por improbidade, impondo-lhes a perda do cargo público comissionado ou impedimento para assumir, cominarão pena que não está

do Executivo estadual na escolha de seus auxiliares, além de disciplinarem matéria de sua iniciativa legislativa, na forma da letra $\mathrm{c}$ do inciso II do $\$ 1$ ○ do art. 61 da Constituicão Federal. Acão julgada procedente. (ADI 217, Relator(a): Min. ILMAR GALVÃO, Tribunal Pleno, julgado em 28/08/2002) Do corpo do acórdão, voto do min. relator Ilmar Galvão: "Registre-se, ademais, que, ao dispor sobre requisitos para preenchimento de postos de chefia na estrutura da Procuradoria do Estado, os dispositivos em questão violaram a iniciativa privativa do Governador para leis que disponham sobre o provimento de cargos. prevista na alínea $\mathrm{c}$ do inciso II do $\S 1^{\circ}$ do art. 61 da Carta da República, regra que, sendo corolário do princípio da separação de poderes, é de observância obrigatório pelos Estados, até mesmo no exercício do poder constituinte decorrente." Mesmo sentido: ADI 2873, Relator(a): Min. ELLEN GRACIE, Tribunal Pleno, julgado em 20/09/2007; ADI 243, Relator(a): Min. OCTAVIO GALLOTTI, Relator(a) p/ Acórdão: Min. MARCO AURÉLIO, Tribunal Pleno, julgado em 01/02/2001; ADI 1165, Relator(a): Min. NELSON JOBIM, Tribunal Pleno, julgado em 03/10/2001; ADI 2856, Relator(a): Min. GILMAR MENDES, Tribunal Pleno, julgado em 10/02/2011; ADI 1895, Relator(a): Min. SEPÚLVEDA PERTENCE, Tribunal Pleno, julgado em 02/08/2007. 
prevista na Lei 8.492/92, lei da improbidade administrativa. Ou melhor, pena há, mas sem o efeito e modo previstos na lei estadual catarinense ${ }^{12}$.

A lei nacional de improbidade condiciona a perda do cargo, ao trânsito em julgado da condenação, desde que a sentença tenha imposto tal pena. Pois alguém pode ter direitos políticos suspensos, sem perda do cargo.

A lei estadual ficha limpa criou regra jurídica que só poderia ser instituída por lei federal e para todos os brasileiros. O inacesso ao cargo público não está entre as penas da lei de improbidade. Apenas a perda do cargo. E só se pode dar tal perda, por sentença judicial, que contenha esse dispositivo em seu campo decisório.

Assim, em solo catarinense, a pessoa que estiver na situação de condenada por improbidade sem trânsito em julgado, e for impedida de assumir cargo em comissão, deve alegar, com serenidade, que tal regra viola as competências legislativas da

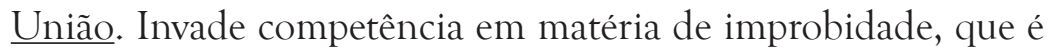
tarefa penal legislativa da União. Invade esfera legiferante cabível à União, e sem competência do Estado de SC ou qualquer outra Unidade da Federação. Trata-se da chamada inconstitucionalidade orgânica. Pois a norma objeto do artigo 1, letra "g", da Lei estadual catarinense n. 15.381/10, viola as normas parâmetros dos artigos 22, I, c/c 37, § 4º da Constituição Federal.

12 "Art. 12. Independentemente das sanções penais, civis e administrativas previstas na legislação específica, está o responsável pelo ato de improbidade sujeito às seguintes cominações, que podem ser aplicadas isolada ou cumulativamente, de acordo com a gravidade do fato: (Redação dada pela Lei $n^{\circ} 12.120$, de 2009). I - na hipótese do art. $9^{\circ},(\ldots)$ perda da função pública, suspensão dos direitos políticos de oito a dez anos, (...); II - na hipótese do art. 10, (...), perda da função pública, suspensão dos direitos políticos de cinco a oito anos, (...); III - na hipótese do art. $11,(\ldots)$ perda da função pública, suspensão dos direitos políticos de três a cinco anos, (...). Parágrafo único. Na fixação das penas previstas nesta lei o juiz levará em conta a extensão do dano causado, assim como o proveito patrimonial obtido pelo agente. (...). Art. 20. A perda da função pública e a suspensão dos direitos políticos só se efetivam com o trânsito em julgado da sentença condenatória." 
4 A LEI ESTADUAL É INVÁLIDA, EM PARTE, POIS SEU CONTEÚDO NORMATIVO CONTRARIA OS PRINCÍPIOS CONSTITUCIONAIS DA PRESUNÇÃO DE INOCÊNCIA E DO DEVIDO PROCESSO LEGAL - VIOLAÇÃO AOS ARTIGOS $5^{\circ}$, LIV E LVII, DA CONSTITUIÇÃO FEDERAL - INCONSTITUCIONALIDADE MATERIAL - DESVALIA PARCIAL E PONTUAL DA LEI CATARINENSE - JURISPRUDÊNCIA DO STF APLICÁVEL POR "ANALOGIA JURIS"

A norma ordinária estadual do artigo $1^{\circ}$, letra "g" ${ }^{13}$, da Lei catarinense n. 15.381/10, viola as normas constitucionais dos artigos 5\%, LIV e LVII, da Constituição Federal. Há inconstitucionalidade material por violação das normas que tratam da presunção de inocência e do devido processo legal.

Isso por que prevê efeito ablador de direito, sem que haja trânsito em julgado de comando condenatório. E efeito tomado a partir de se reconhecer, sem definitividade, sem trânsito em julgado, a situação de condenado.

Foi violado, pela lei estadual, o princípio da presunção de inocência, que não contém sua aplicação apenas à esfera penal, como conquista da Ciência Jurídica contemporânea.

E essa inconstitucionalidade trouxe outro grande inconveniente ideológico: os defensores "da constitucionalidade" e "da bondade da lei ficha limpa teem tomado posições de "conveniência e oportunidade”, mesmo contra consagradas posições na Teoria do Direito e na Ciência Jurídica em geral. Eles dizem que esse princípio, o da presunção de inocência, só teria aplicação na esfera do Direito Penal. E o fazem "apenas" para defender a

13 "Art. 1 Fica vedada a nomeação para cargos em comissão no âmbito dos órgãos dos Poderes Executivo, Legislativo, Judiciário e do Tribunal de Contas do Estado às pessoas inseridas nas seguintes hipóteses: (...) g) os que forem condenados à suspensão dos direitos políticos, em decisão transitada em julgado ou proferida por órgão judicial colegiado, por ato doloso de improbidade administrativa que importe lesão ao patrimônio público e enriquecimento ilícito, desde a condenação ou o trânsito em julgado até o transcurso do prazo de 8 (oito) anos após o cumprimento da pena." 
lei, com argumento indefensável perante o tribunal da razão e da ciência.

Ora, é conquista da civilidade e da Ciência jurídica dela resultante, que tal princípio tem aplicação em todos os ramos do Direito onde haja atividade sancionadora, função punitiva. Tanto que se fala, hoje, de Direito Sancionador para abarcar amplas esferas para além do Direito Penal, que, todavia, pressupõe a Ciência Penal como o grande arquétipo, a grande luz, o grande caminho que orienta a aplicação das penas em todas as áreas do Direito.

Podem querer dizer os apologistas da "moral por sobre o direito" que inacessibilidade não seria pena, sanção, restrição punitiva a direito. Por tanto, o princípio da presunção de inocência não lhe poderia emprestar qualquer favor. Inacessibilidade da lei estadual seria "mero requisito" para se prover cargo público em comissão no executivo catarinense, aferível na data de posse de cada agente. Ademais, para o discurso moralista o direito político de participar da coisa pública, por meio de cargos políticos sem concurso, deve curvar-se ao interesse público, ao interesse social de barrar "pessoas" moralmente espúrias.

Para esse entendimento, o direito fundamental político de participar da coisa pública (liberdade-participação) não seria garantia dos indivíduos, garantia fundamental, apenas interesse público moldado pela opinião pública majoritária, e momentaneamente dominante, que, em dado momento histórico, define o que é interesse público e o que deve ser "moralmente imposto", nem sempre ouvindo a "vontade de constituição" (Konrad Hesse) ou o "sentimento constitucional" (Pablo Lucas VERDU).

Esse tipo de discurso não pode ser aceito pela comunidade constituída por regime democrático e regida por Constituição garantidora de direitos fundamentais. 
Decisões do STF afirmam ${ }^{14}$ que para prover cargos por concurso público, não se pode obstruir, por lei ou edital, o direito de inscrição ou de investidura com base em questões criminais ou de improbidade ainda não transitadas em julgado. Igual postura interpretativa sustenta o STJ, em recentíssimo acórdão. ${ }^{15}$

14 "RE 634.224/DF RELATOR: Min. Celso de Mello EMENTA: CONCURSO PÚBLICO. INVESTIGAÇÃO SOCIAL. VIDA PREGRESSA DO CANDIDATO. EXISTÊNCIA, CONTRA ELE, DE PROCEDIMENTO PENAL. EXCLUSÃO DO CANDIDATO. IMPOSSIBILIDADE. IRANSGRESSÃO AO POSTULADO CONSTITUCIONAL DA PRESUNÇÃO DE INOCÊNCIA (CF, ART. $5^{\circ}$, LVII). RECURSO EXTRAORDINÁRIO IMPROVIDO. - A exclusão de candidato regularmente inscrito em concurso público, motivada, unicamente, pelo fato de haver sido instaurado, contra ele, procedimento penal, sem que houvesse, no entanto, condenação criminal transitada em julgado, vulnera, de modo frontal, o postulado constitucional do estado de inocência, inscrito no art. $5^{\circ}$, inciso LVII, da Lei Fundamental da República. Precedentes. "O POSTULADO CONSTITUCIONAL DA PRESUNCÃO DE INOCÊNCIA IMPEDE QUE O ESTADO TRATE, COMO SE CULPADO FOSSE, AQUELE QUE AINDA NÃO SOFREU CONDENACÃO PENAL IRRECORRIVEL. (...) O que se mostra relevante, a propósito do efeito irradiante da presunção de inocência, que a torna aplicável a processos (e a domínios) de natureza não criminal, é a preocupação, externada por órgãos investidos de jurisdição constitucional, com a preservação da integridade de um princípio que não pode ser transgredido por atos estatais (como a exclusão de concurso público motivada pela mera existência de procedimento penal em curso contra o candidato) que veiculem, prematuramente, medidas gravosas à esfera jurídica das pessoas, que são, desde logo, indevidamente tratadas, pelo Poder Público, como se culpadas fossem, porque presumida, por arbitrária antecipação fundada em juízo de mera suspeita, a culpabilidade de quem figura, em processo penal ou civil, como simples réu! (...). Publique-se. Brasília, 14 de março de 2011. decisão publicada no DJe de 21.3.2011."

"RE 565519/DF RELATOR: Min. Celso de Mello EMENTA: POLÍ́cIA MILITAR DO DISTRITO FEDERAL. CURSO DE FORMAÇÃO DE SARGENTOS (PM/DF). CABO PM. NÃO CONVOCAÇÃO PARA PARTICIPAR DESSE CURSO, PELO FATO DE EXISTIR, CONTRA REFERIDO POLICIAL MILITAR, PROCEDIMENTO PENAL EM FASE DE TRAMITAÇÃO JUDICIAL. EXCLUSÃO DO CANDIDATO. IMPOSSIBILIDADE. TRANSGRESSÃO AO POSTULADO CONSTITUCIONAL DA PRESUNCCÃO DE INOCÊNCIA (CF, ART. $5^{\circ}$, LVII). RECURSO EXTRAORDINÁRIO IMPROVIDO. (...) Publique-se. Brasília, 13 de maio de 2011."

15 "ADMINISTRATIVO. CONCURSO PÚBLICO. INABILITAÇÃO NA FASE DE INVESTIGAÇÃO SOCIAL. EXISTÊNCIA DE INQUÉRITOS POLICIAIS, AÇÕES PENAIS EM ANDAMENTO OU INCLUSÃO DO NOME DO CANDIDATO EM SERVIÇO DE PROTEÇÃO AO CRÉDITO. PRINCÍPIO DA PRESUNÇÃO DE INOCÊNCIA. 1. Não havendo sentença condenatória transitada em julgado, o princípio da presunção de inocência resta maculado, ante a eliminação de candidato a cargo público, ainda na fase de investigação social do certame, por ter sido verificada a existência de inquérito ou ação penal. 2. É desprovido de razoabilidade e proporcionalidade o ato que, na etapa de investigação social, exclui candidato de concurso público baseado no registro deste em cadastro de 
Mesmo em tema de inelegibilidade, justamente no caso da lei ficha limpa, o STF tem precedente em tema da improbidade administrativa sem trânsito em julgado ${ }^{16}$, que demonstra a escancarada invalidade da lei estadual.

serviço de proteção ao crédito. 3 . Recurso ordinário em mandado de segurança conhecido e provido." RECURSO EM MANDADO DE SEGURANÇA № 30.734 DF, RELATORA MINISTRA LAURITA VAZ, Quinta Turma, DJe 04.10.11.

16 Vale a atenta leitura desses precedentes, que são demais esclarecedores e convincentes do acerto de suas premissas: (....). "AC 2763-MC/RO* RELATOR: Min. Celso de Mello EMENTA: REGISTRO DE CANDIDATURA. LEI COMPLEMENTAR No 135, DE 04 DE JUNHO DE 2010. (...) PRESUNCÃO CONSTITUCIONAL DE INOCENNCIA: UM DIREITO FUNDAMENTAL QUE ASSISTE A QUALQUER PESSOA (ADPF 144/DF, REL. MIN. CELSO DE MELLO). PRERROGATIVA ESSENCIAL, IMPREGNADA DE EFICÁCIA IRRADIANTE, ESPECIALMENTE AMPARADA, EM TEMA DE DIREITOS POLÍTICOS, PELA CLÁUSULA TUTELAR INSCRITA NO ART. 15, III, DA CARTA POLÍTICA, QUE EXIGE, PARA EFEITO DE VÁLIDA SUSPENSÃO DAS DIMENSÕES (ATIVA E PASSIVA) DA CIDADANIA, $\underline{0}$ TRÂNSITO EM JULGADO DA CONDENAČÃO CRIMINAL. O ALTO SIGNIFICADDO POLÍTI-

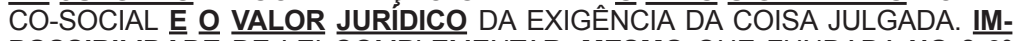
POSSIBILIDADE DE LEI COMPLEMENTAR, MESMO QUE FUNDADA NO § $\underline{9}^{\circ}$ DO ART. 14 DA CONSTITUIÇÃO, TRANSGREDIR A PRESUNÇÃO DE INOCẼNCIA, PELO FATO DE REFERIDA ESPÉCIE NORMATIVA QUALIFICAR-SE COMO ATO HIERARQUICAMENTE SUBORDINADO À AUTORIDADE DO TEXTO EE DOS PRINCÍPIOS CONSTITUCIONAIS. DECISÃO DO E. TRIBUNAL SUPERIOR ELEITORAL QUE DENEGOU REGISTRO DE CANDIDATURA, SOB O FUNDAMENTO DA MERA EXISTÉNCIA, CONTRA O CANDIDATO, DE CONDENAÇÃO PENAL EMANADA DE ÓRGÃO COLEGIADO, EMBORA QUESTIONADA ESTA EM SEDE RECURSAL EXTRAORDINÁRIA. CONSEQÜENTE INEXISTÊNCIA DO TRÂNSITO EM JULGADO DE REFERIDA CONDENAÇÃO CRIMINAL. (...). - PROBIDADE ADMINISTRATIVA, MORALIDADE PARA O EXERCÍCIO DO MANDATO ELETIVO, 'VITA ANTEACTA' E PRESUNCCÃO CONSTITUCIONAL DE INOCÊNCIA - SUSPENSÃO DE DIREITOS POLIITICOS E IMPRESCINDIBILIDADE, PARA ESSE EFEITO, DO TRÂNSITO EM JULGADO DA CONDENACCÃO CRIMINAL (CF, ART. 15, III) - (...) O PROCESSO PENAL COMO DOMIINIO MAIS EXPRESSIVO DE INCIDÉNCIA DA PRESUNÇÃO CONSTITUCIONAL DE INOCENNCIA EFICÁCIA IRRADIANTE DA PRESUNÇÃO DE INOCÊNCIA - POSSIBILIDADE DE EXTENSÃO DESSE PRINCÍPIO AO ÂMBITO DO PROCESSO ELEITORAL - HIPOTESES DE INELEGIBILIDADE - ENUMERACÃO EM ÂMBITO CONSTITUCIONAL (CF, ART. 14, $\left.\S \S 4^{\circ} A 8^{\circ}\right)$ - RECONHECIMENTO, NO ENTANTO, DA FACULDADE DE O CONGRESSO NACIONAL, EM SEDE LEGAL, DEFINIR' 'OUTROS CASOS DE INELEGIBILIDADE' - NECESSÁRIA OBSERVẤNCIA, EM TAL SITUAÇÃO, DA RESERVA CONSTITUCIONAL DE LEI COMPLEMENTAR ( $\underline{C}$, ART. 14, $\left.\S 9^{\circ}\right)$ - IMPOSSIBILIDADE, CONTUDO, DE A LEI COMPLEMENTAR, MESMO COM APOIO NO § $9^{\circ}$ DO ART. 14 DA CONSTITUIÇÃO, TRANSGREDIR A PRESUNÇÃO CONSTITUCIONAL DE INOCENNCIA, QUE SE QUALIFICA COMO VALOR FUNDAMENTAL, VERDADEIRO 'CORNERSTONE' EM QUE SE ESTRUTURA O SISTEMA QUE A NOSSA CARTA POLITICA CONSAGRA EM RESPEITO AO REGIME DAS LIBERDADES E EM DEFESA DA PRÓPRIA PRESERVAÇÃO DA ORDEM DEMOCRÁTICA - PRIVACCÃO DA CAPACIDADE ELEITORAL PASSIVA E PROCESSOS, DE NATUREZA CIVIL, POR IMPROBIDADE ADMINISTRATIVA - NECESSIDADE, TAMBÉM EM TAL HIPÓTESE, DE CONDENACÁO IRRECORRÍVEL - COMPATIBILIDADE DA LEI No 8.429/92 (ART. 20, “CAPUT') COM A CONSTITUICÃOO FEDERAL (ART. 15, V, C/C O ART. 37, \& $\left.4^{\circ}\right)$ - O SIGNIFICADO POLITICO E O VALOR JURIDICO DA EXIGÉNCIA DA COISA JULGADA - (...).".'(ADPF 144/DF, Rel. Min. CELSO DE MELLO, Pleno) (...). Publique-se. Brasília, 16 de dezembro de 2010. DJe de $1^{\circ} .2 .2011 . "$ 
Diante da pacífica e convincente jurisprudência do STF, o cidadão que estiver na situação de condenado por improbidade sem trânsito em julgado, e for impedido de assumir cargo em comissão no Estado de SC, deve alegar em seu prol, com serenidade, que tal regra violou presunção de inocência, inscrita na Carta Federal, enquanto regra de tratamento e garantia processual constitucional.

5 O DISPOSITIVO LEGAL ESTADUAL É INVÁLIDO, POIS SEU CONTEÚDO NORMATIVO CONTRASTA COM OS PRINCÍPIOS CONSTITUCIONAIS DA SEGURANÇA JURÍDICA, PROTEÇÃO DA CONFIANÇA, COISA JULGADA E ISONOMIA - ALCANÇA FATOS QUE ENSEJARAM A CONDENAÇÃO POR IMPROBIDADE OU DECISÃO COLEGIADA QUE ANTECEDERAM A ENTRADA EM VIGOR DA LEI ESTADUAL - NORMA PREJUDICIAL ESTATUÍDA COM FINS PUNITIVOS RETROATIVOS - VIOLAÇÃO AOS ARTIGOS 5', CAPUT, E XXXVI DA CONSTITUIÇÃO FEDERAL INCONSTITUCIONALIDADE MATERIAL - DESVALIA PONTUAL DA LEI EM SEU ARTIGO 1, LETRA “G”

Os princípios constitucionais da segurança jurídica, da proteção da confiança, da coisa julgada e da isonomia também foram violados, porque a lei estadual, no dispositivo em foco, tem nítido conteúdo lesivo e retroativo aos que praticaram atos tidos com ímprobos e/ou foram condenados antes de sua entrada em vigor.

Tomemos como exemplo elucidativo desta inconstitucionalidade, o seguinte caso hipotético: os fatos caracterizadores de improbidade se deram entre 11.10 .02 e 11.11.02. Nessa época, demonstra o Direito Positivo, não vigorava qualquer norma nacional ou estadual que emprestasse tal efeito sancionatório - inacessibilidade a cargos em comissão no Poder Executivo de SC - a prática desses atos. 
Por outro lado, partamos da hipótese de que houve acórdão em 05.08.09, que confirmou a condenação (ou a decretou). Nessa data também não havia qualquer norma da ordem jurídica nacional ou estadual, anexando tais efeitos a uma decisão judicial em casos de improbidade, seja de primeiro ou de segundo grau de jurisdição cível.

A norma que vigia e vigora para os fatos ocorridos entre 2002 e 2010, regulando a matéria, é a Lei nacional 8.429/92, que nada tratou sobre o tema inacessibilidade a cargos em comissão, nos termos postos pela lei ficha limpa estadual, que só veio à vigência em 20.12.10, data de sua publicação no diário oficial do Estado de

A violação à segurança jurídica e à proteção da confiança, se dá, por que entre a prática dos comportamentos tidos como ímprobos e a edição da lei que deseja valorá-los de forma sancionatória, em termos retroativos, transcorreram 8 anos e dois meses! Ou seja, após a prática consolidada de tais atos (para o bem ou para o mal), surgiu na ordem jurídica estadual regra que "juridiciza fatos passados", para impedir o exercício de liberdades no presente, a liberdade-participação de acesso a cargos em comissão nos poderes constituídos em SC. Surgiu, no presente, norma-sanção para emprestar a fatos passados efeito limitador ao direito de liberdade-participação.

E tendo em conta o tempo de prolação do acórdão, a diferença temporal, embora menor relativamente à data de ocorrência dos fatos, não é menos desautorizante de incidência válida da nova lei estadual: 1 ano e 4 meses do acórdão. Assim, neste particular, a lei estadual estatuir novo efeito anexo para decisões judiciais já prolatadas, constitui flagrante violação à garantia constitucional da coisa julgada.

E toda lei retroativa punitiva ou gravosa à esfera de direitos da pessoa humana, que busca enredar em sua esfera de juridicidade fatos já consolidados ou sentença já dadas, viola a regra da isonomia. Pois é lei que visa regular, retrospectivamente, casos certos, dados sobre pessoas certas, eis que o passado é certo, mas o futuro não. 
A generalidade (universo de pessoas) e abstração (universo de casos) da lei são garantias da igualdade (Norberto Bobbio). E como as leis regulam para o futuro, sua abstração e generalidade guarnecem a igualdade de tratamento de todos os cidadãos não só perante as leis, mais no interior de seus comandos normativos. Lei nova que colhe fatos ou sentenças passadas tem endereço certo, pois já sabe que pessoas receberão sua incidência e que casos concretos ocorreram. Sabe quais casos concretos e quais indivíduos afetará, pois dispõe da certeza do passado! Abarca, retroativamente, no plano do concreto e do individual, pessoas e casos determinados, pois já dados, como o de exemplo antes dado. Tais leis, em nosso sistema de direitos, "não tem futuro para aplicação passada!”. E futuro só terão se respeitarem o passado!

Lembremos, a propósito, um rico filme sobre o tema (retroatividade gravosa e injusta das leis), de Costa Gravas, Corte Especial de Justiça, que apresenta o que fizeram os nazistas com a França invadida, para retaliarem os ataques que a resistência francesa impingia aos oficias do exército tedesco no centro de Paris: as forças de ocupação alemã rejulgaram, com novas regras e novas penas, presos já detidos e em cumprimento de sentenças... e decretaram a pena de morte, para muitos casos de furto, para os quais o Direito pré-ocupação previa apenas privação de liberdade! Assim, intolerável que em pleno vigor de nossa democracia retornemos às práticas de regimes que lhe são o contrário e/ou a sua própria morte (in)jurídica! ${ }^{17}$

Todavia, ainda que se pudesse dizer o artigo 1\%, letra "g", da Lei estadual válido, ele só o seria pró-futuro; só poderia incidir, válida e eficazmente, sobre fatos ocorriveis a partir de sua entrada em vigor - a partir de 20.12.10. Ou seja, a lei ficha limpa estadual só pode ter efeitos prospectivos, no dia imediato e posterior a 20.12.10, ou melhor, seus efeitos devem projetar-se

17 Como crítica a esse tipo de postura, ver: Ruy Samuel Espíndola. A Constituição como Garantia da Democracia: o papel dos Princípios Constitucionais. Revista de Direito Constitucional e Internacional. Cadernos de Direito Constitucional e Ciência Política. São Paulo: Revista dos Tribunais/Instituto Brasileiro de Direito Constitucional, ano 11, abr./jun. 2003, n. 44. 
para o futuro; incidirem apenas sobre fatos ocorríveis a partir de sua entrada em vigor, e jamais ex tunc (retroatividade), sob pena de incidência retroativa de leis gravosas em matéria de liberdades e de direito estrito. Com outras letras: os fatos típicos que terão os efeitos de barrar acesso a cargos em comissão, devem se dar no mundo do ser do direito, após a entrada em vigor da lei ficha limpa (20.12.10), nunca antes!

A doutrina juseleitoral de Adriano da Costa Soares ${ }^{18}$,

18 Crítica que serve à normativa estadual em foco. Para sermos fiéis à doutrina, traremos, entre colchetes, ao lado do termo "inelegibilidade", a categoria "inacessibilidade": Texto de doutrina de ADRIANO DA COSTA SOARES encontrável em blog multicitado nas últimas decisões do STF - http://adrianosoaresdacosta.blogspot. com: "PONTES DE MIRANDA tem um texto maravilhoso sobre conflito de leis no tempo nos Comentários à Constituição de 1946, Rio de Janeiro: Borsói, tomo IV, p.399, em que afirma, com grifos apostos: "A lei nova não fica adstrita aos fatos de hoje e de amanhã; o que se dá, rigorosamente, é que ela se restringe ao tempo de hoje e ao de amanhã, até que outra lei corte este amanhã, o pontue, criando o hoje da nova denominação legal, o seu hoje e o seu amanhã. Em vez de uma análise dos fatos, ou de direitos (critério subjetivo), uma análise do tempo, ou melhor, dos lapsos de tempo". A lição de Pontes de Miranda mostra que não estamos, no direito intertemporal, diante da regra absoluta de que os fatos de ontem não possam ser apanhados pela regra de hoje (a lei nova). Essa regra absoluta existe no direito penal, quando a Constituição Federal prescreve que não há crime sem lei anterior que o defina. É dizer, não apenas aos efeitos da lei há interdição à retroatividade (plano da eficácia); a própria lei há de ser anterior ao fato ilícito (plano da existência da lei). Em matéria penal, de conseguinte, a regra sobre irretroatividade é absoluta. E essa norma de sobredireito alcança as normas que criam penas principais ou acessórias de natureza criminal, ainda que não constem no corpo do Código Penal. É o caso da alínea "e" do inciso I do art. $1^{\circ}$ da LC 64/90, com a redação dada pela LC 135/10. Trata-se de previsão de pena acessória (inelegibilidade por 8 anos) a ser anexada à sentença penal condenatória, independentemente do trânsito em julgado, bastando que exista decisão colegiada (em explícita violação ao art.15, III, da CF/88). Outra coisa, nada obstante, ocorre com as demais normas da LC 64/90, com a redação da LC 135/10. Aqui, a discussão tem outra natureza. A questão a saber é se a lei nova poderia (i) criar condições de elegibilidade [inacessibilidade] a ser aplicada de imediato para o próximo pleito eleitoral e, também, se poderia (ii) criar hipóteses novas de inelegibilidade [inacessibilidade] para fatos ilícitos passados [2002 e 2005] já ocorridos antes da vigência da lei nova [2010] (......" "Se há inelegibilidade [inacessibilidade] cominada potenciada, prescreve a lei do tempo ou (a) do fato ilícito [2002 e 2005] eleitoral (ou não eleitoral, como o crime contra a fé pública, v.g.) ou (b) da relação processual [2009], se a sanção for efeito anexo da sentença, transitada ou não em julgado. Sendo sanção, a interpretação é sempre de direito estrito; restritiva, portanto. Nos dois casos, responde o direito intertemporal, em que a Constituição Federal de 1988 prescreveu o princípio da irretroatividade e do respeito ao ato jurídico perfeito, à coisa julgado e ao direito adquirido. Erram palmarmente a $O A B$ e os que lhe inspiraram a fala. $E$ é triste que assim seja, pela fundamental importância da OAB na defesa do Estado Democrático de Direito. Erram porque não se deve relacionar o tempo da lei nova eleitoral [lei administrativa de vedação de provimento em cargo público estadual] com o tempo do registro de candidatura [tempo do provimento ao cargo], mas, 


\section{discutindo dispositivo similar constante da lei complementar 135/10, fez precisa crítica ao dispositivo federal. Embora trate,}

sim, confrontá-la com o tempo do ato ilícito que fez nascer a inelegibilidade ou com o tempo da relação processual em cuja decisão anexou-se a sanção. (...) Para que a garantia do devido processo legal? Para que a garantia da ampla defesa e do contraditório? Afinal, como demonstra Ingo Wofgang Sarlet ( $\boldsymbol{A}$ eficácia dos direitos fundamentais. Porto Alegre: Livraria dos Advogados, 1998, p.249), há plena eficácia dos direitos de defesa como direitos fundamentais, devendo ter a máxima efetividade garantida pelo $\S 1^{\circ}$ do art. $5^{\circ}$ da CF/88, integrados que são aqueles direitos pelos direitos de liberdade, igualdade, direitos-garantias, garantias institucionais, direitos políticos [liberdade-participação, por provimento em emprego ou cargos públicos em comissão] e posições jurídicas fundamentais em geral, "que, preponderantemente, reclamam uma atitude de abstencão dos poderes estatais e dos particulares (como destinatários dos direitos)". Uma última afirmação: se as restrições aos direitos políticos forem tomadas como restrição a direito fundamental, na linha do posicionamento do STF na ADPF 144/ DF, então a distinção que fiz entre tratamento diverso aos efeitos inclusos e anexos à sentença se evanescem, dando-se a máxima efetividade ao princípio da presunção de inocência e ao princípio da irretroatividade. (...) o legislador pôs na mesma norma, indistintamente, inelegibilidade [inacessibilidade] decretada como conteúdo de uma decisão judicial (efeito inexo ou incluso) e inelegibilidade [inacessibilidade] decorrente de efeito anexo ou excluso, aplicada ope legis como pena acessória (aqui, naturalmente, não há como fugir da incidência do art.15, III, da CF/88, no caso de sentença penal condenatória, a exigir sempre o trânsito em julgado para efeito de suspensão dos direitos políticos). Pena que os panfletos divulgados pelas entidades que defendem a aplicação imediata das normas da nova lei complementar não cuidem dessas relevantes questões jurídicas. Gostaria de fazer aqui uma importante observação, essencial para prosseguirmos: a inelegibilidade [inacessibilidade] cominada é sanção que pode ser conteúdo ou efeito anexo da sentença. Em ambos os casos, a inelegibilidade é conteúdo ou efeito da sentença! A afirmação é um truísmo, mas em tempos obscurantistas fazse fundamental avivarmos questões básicas. Se o efeito é incluso à sentença, fazendo parte do conteúdo da decisão, é porque a inelegibilidade [inacessibilidade] é efeito do fato jurídico ilícito, estando pois na relação de direito material. sendo constituída pela decisão judicial que primeiramente declarou que o ato lícito se deu. Ou seja, a inelegibilidade [inacessibilidade] se liga primeiramente ao ato ilícito, sendo constituída como sanção à sua prática. Assim, a questão fundamental é saber se ao tempo do fato a lei o previa como ilícito e se a ele cominava aquela sanção. Se a sanção derivar de lei posterior, aplicá-la seria dar-lhe efeito retroativo, revolvendo inconstitucionalmente o passado. Diversamente, como efeito anexo da decisão judicial, a norma não desce aos fatos ilícitos mesmos, mas toma a decisão judicial sobre eles como ato-fato jurídico, sobre o qual faz incidir a inelegibilidade [inacessibilidade] como efeito anexo. A questão jurídica seria diversa: não seria o caso de se olhar se o fato ilícito eleitoral foi anterior ou posterior à lei, mas sim se: (a) já há relação jurídica processual [o feito de improbidade contra o cidadão $X$ foi instaurado em 2007, para continuarmos no exemplo hipotético antes apresentado!]; e (b) se já há decisão judicial em que os efeitos da inelegibilidade [inacessibilidade]serão anexados. É evidente que a lei que criou a sanção como efeito anexo da sentença tenha que ser, para ter efeito, anterior à formação da relação processual, quando já estabilizada pela contestação (princípio da eventualidade). E com muito mais razão, é evidente também que não há como se soldar o efeito anexo a decisões já proferidas quando a lei nova ingressou em vigor. Nem em um caso nem no outro há possibilidade de aplicação da nova lei, salvo se for para lhe atribuir retroatividade." 
em parte, de condenação criminal, ela se aplica, tout court, às condenações de improbidade, não só pelo evidente conteúdo penal não criminal dessas decisões, mas por que em nosso sistema de direito não pode haver leis gravosas retroativas, por força do princípio da irretroatividade das leis.

Suas lições embora discorram mais sobre decisão criminal, se aplicam, igualmente, aos casos de improbidade, como afirmamos. Pois a sentença que aplica penas da Lei 8.429/92 é sentença penal, por que aplica penas restritivas de direitos e de caráter pecuniário. Ela apenas não é sentença criminal, mas é penal cível!

Outra agressão às garantias constitucionais foi o fato da lei ficha limpa alcançar (eleitoral e estadual catarinense) fatos ocorridos no passado, emprestando-lhes consequências novas e inesperadas, não existentes no momento em que foram praticados ou não cogitados nos processos em que foram sentenciados.

Agressão violenta às regras constitucionais da coisa julgada, do direito adquirido, do ato jurídico perfeito, e dos princípios da segurança jurídica e ao princípio da não-surpresa e da lealdade e confiança nos atos de Estado.

Vide caso Jader em que sua renúncia ocorreu há 09 anos (outubro de 2001), sendo que ele já fora eleito, duas vezes, nesse período, para a Câmara dos Deputados!!!

Tal agressão ao direito político de candidatura e ao direito político fundamental de acesso a cargos públicos em comissão, que são liberdades-participação, não tem exemplo similar em nosso Direito Constitucional ou Eleitoral, e "se a onda pegar" em outras ramos do Direito, poderemos pagar multas de trânsitos por fatos não ilícitos no passado, mas tornados tais no presente; pagar tributos por fatos geradores ocorridos há muito; responder, no presente, por condutas taxadas de crime hoje, mas que no passado, quando praticadas, não o eram.

A lei eleitoral, neste aspecto, tinha endereço certo, era alcançar determinados parlamentares (Jader, Roriz, etc - 
ACM escapou, pois morreu antes...), que nos últimos anos, renunciaram para escapar a processos ético-disciplinares. E a lei ficha limpa estadual, igualmente.

Ora, apuremos casos como esses através das devidas ações penais, ações de responsabilidade por ato de improbidade, procedimentos responsabilizatórios nos Tribunais de Contas, e nas demais vias legais de responsabilização desses agentes. Contudo, utilizar de tais meios o legislador eleitoral o estadual, ainda que com apelo popular, é praticar ato juridicamente inconstitucional e moralmente questionável.

Nenhum cidadão fã de futebol aceitaria que no meio de uma partida, o juiz alterasse, com surpresa a todos, as regras do jogo, para atingir um resultado previamente querido por ele! Nas eleições não pode ser diferente, ainda que com alto ruído da claque.

Embora politicamente correto o fim, juridicamente abjeto o meio! Não podemos tolerar leis com esse casuísmo.

A lei deve ser geral, abstrata e pró-futuro. Pois deve se aplicar a todas as pessoas, indistintamente; prever hipoteticamente uma série relevante de comportamentos vedados, proibidos ou permitidos; e deve valer para o amanhã, para que possamos dela saber com antecedência, e descobrirmos, racionalmente, os caminhos do lícito e/ou do ilícito, avaliando previamente seus custos e riscos, nossos deveres, direitos e responsabilidades." 19

19 Conforme Ruy Samuel Espíndola. "A Lei ficha limpa em revista e os empates no STF: as liberdades políticas em questão e o dilema entre o politicamente correto e o constitucionalmente sustentável." In: - George Salomão Leite (coord.) Direitos, Deveres e Garantias Fundamentais. Bahia, Juspodium, 2011p. 781/798, p. 793/794. Esse livro constitui anais do $9^{\circ}$ Congresso Internacional de Direito Constitucional, ocorrido em Natal/RN, entre os dias 28/30 abril 2011, sob os auspícios da Escola Brasileira de Estudos Constitucionais. E o artigo constitui expressão escrita de nossa conferência no painel "Liberdades Políticas e Justiça Eleitoral Contramajoritária: a democracia entre o moralismo e o devido processo legal." Outra versão deste estudo encontra-se na web: ESPÍNDOLA, Ruy Samuel. A Lei Ficha Limpa em revista e os empates no STF. O dilema entre o politicamente correto e o constitucionalmente sustentável. Jus Navigandi, Teresina, ano 15, n. 2711, 3 dez. 2010. Disponível em: <http://jus.uol.com.br/revista/texto/17925>. Acesso em: 1 maio 2011. 
Há outro ensaio do estudioso Milton Cordova Júnior, cujas conclusões são ricas ao tema (e caso) em análise ${ }^{20}$.

A lição mais contundente sobre o assunto, a demonstrar higidez dessa tese de invalidade da lei estadual, vem do voto do Ministro Celso De Mello no RE 630.147/DF, ao analisar a retroatividade da lei complementar n. 135/10, afetante do direito politico fundamental de candidatura. Suas conclusões são aplicáveis a demonstrar a retroatividade lesiva da lei ficha limpa estadual ao direito político fundamental de acesso a cargos públicos em comissãa ${ }^{21}$.

20 Cf. seu "Retroatividade da lei da ficha limpa: O Supremo Tribunal Federal não é o limite". Jus Navigandi, Teresina, ano 15, n. 2681, 3 nov. 2010. Disponível em: <http://jus.uol.com.br/revista/texto/17753>. Acesso em: 3 nov. 2010.

21 "Na realidade, a decisão do Tribunal Superior Eleitoral, ao reconhecer a (inadmissível) possibilidade de o legislador imputar, ao ato de renúncia (aperfeiçoado, no passado, segundo o ordenamento positivo então vigente), a irradiação de um novo e superveniente efeito claramente restritivo do direito fundamental de participação política, incorreu em ofensa à cláusula inscrita no inciso XXXVI do art. $5^{\circ}$ da Constituição, que assegura a incolumidade do ato jurídico perfeito e que obsta, por isso mesmo, qualquer conduta estatal que provoque, mediante restrição normativa superveniente, a desconstrução ou a modificação de situações jurídicas lícitas e definitivamente consolidadas, ainda mais quando se lhes agregam consequências sequer autorizadas pela legislação em vigor no momento em que se formulou a declaração unilateral de vontade, cuja eficácia resultou do que ainda se contém no $\S 4^{\circ}$ do art. 55 da Constituição Federal. Desse modo, entendo assistir razão ao candidato ora recorrente, quando invoca, com inteira correção, os fundamentos evidenciadores da aplicação inconstitucional, ao caso ora em exame, da regra inscrita na alínea "k" do inciso I do art. $1^{\circ}$ da $L C n^{\circ}$ 64/90, na redação dada pela Lei Complementar $n^{\circ} 135 / 2010$ [assim o artigo $1^{\circ}$, letra " $g$ ", da Lei estadual]. (...). 0 acórdão recorrido, ao aplicar, retroativamente, o preceito inscrito na alínea "k" do inciso I do art. $1^{\circ}$ da LC $n^{\circ}$ 64/90, na redação dada pela LC $n^{\circ} 135 / 2010$, também desrespeitou, de modo claro e inequívoco, outro postulado fundamental, impregnado de vocação protetiva, inscrito no art. $5^{\circ}, \mathrm{XXXVI}$, da Carta Federal, que objetiva resquardar a incolumidade das situações jurídicas definitivamente estabelecidas. (...). A circunstância de as leis terem efeito imediato não legitima a interpretação que o Tribunal Superior Eleitoral deu à Lei Complementar no 135/2010, fazendo-a incidir, de modo inconstitucional, sobre situação pretérita que, além de exaurida em todas as suas potencialidades jurídicas, já se achava definitivamente consolidada no tempo, como sucedeu com a renúncia do ora recorrente ao mandato parlamentar, por ele formalizada anos antes da vigência do diploma legislativo referido... (...). O fato a ser destacado, neste ponto, Senhores Ministros, considerado o fundamento da eficácia imediata das leis, subjacente ao julgamento proferido pelo Tribunal Superior Eleitoral, é que o sempre invocado magistério de PAUL ROUBIER ("Le Droit Transitoire", $2^{\mathrm{a}}$ ed., 1960) encontra insuperável limitação de ordem jurídica no próprio sistema constitucional brasileiro, que, ao contrário da realidade normativa vigente na França, não convive com atos 
E para referendar a tese de que a lei ficha limpa estadual contraria a coisa julgada, há precedente de 05.05.11, do TSE, Relator Ministro Marco Aurélio, no Agravo Regimental em Recurso Ordinário no 877-54/RJ: "INELEGIBILIDADE - COISA JULGADA - LEI COMPLEMENTAR No 135/2010 - RETROAÇÃO MÁXIMA. Contraria, a mais não poder, a primeira condição da segurança jurídica - a irretroatividade da lei - olvidar, colocar em plano secundário, ato jurídico perfeito por excelência - a coisa julgada -, ante a Lei Complementar n ${ }^{\circ} 135 / 2010$, implementando-se retroatividade máxima. DJE de 4.5.2011."

Para evidenciar transgressão ao princípio constitucional da proteção da confiança, pela lei ficha limpa estadual, basta o afirmado pelo Ministro Luiz Fux do STF, em voto de desempate no RE 633703/MG - Relator Min. Gilmar Mendes ${ }^{22}$.

estatais, que, aplicados retroativamente (ainda que se cuide de retroatividade mínima), afetem as situações jurídicas definitivamente consolidadas ou interfiram nas consequências que delas emanaram como resultado causal necessário ou atribuam, em caráter inovador, a fatos pretéritos já consumados no tempo, efeitos gravosos e restritivos de direitos, notadamente de direitos essenciais como aqueles que se contêm no conceito de liberdade - participação (como o direito de disputar mandatos eletivos, p. ex.).(...).A aplicação retroativa da norma legal em causa (alínea " $k$ ") [e " $g$ ", do artigo $1^{\circ}$, da lei estadual] - que afeta, sensivelmente, de modo direto, o "status activae civitatis" do candidato - expõese à censura jurídica (...). Em suma: tenho para mim que se mostra plenamente acolhível a pretensão recursal deduzida nesta causa, considerados, para tanto, os fundamentos concernentes, quer à violação do princípio da anterioridade eleitoral (CF, art. 16), quer à ofensa à cláusula de incolumidade do ato jurídico perfeito, cuja transgressão, no caso, resultou de interpretação judicial, proferida pelo E. Tribunal Superior Eleitoral, evidentemente lesiva ao postulado da irretroatividade das leis (CF, art. $5^{\circ}, \mathrm{XXXVI)}$. Sendo assim, em face das razões expostas e reafirmando o voto por mim anteriormente proferido no julgamento do RE 630.147/DF peço vênia para conhecer e dar provimento ao presente recurso extraordinário, assegurando, desse modo, ao candidato recorrente, o direito ao registro de sua candidatura. É o meu voto."

22 "Os efeitos imediatos da Lei Complementar n 135, de 04 de junho de 2010 infringem o princípio da proteção da confiança, difundido no Direito germânico e que, mais recentemente, ganha espaço no cenário jurídico brasileiro. Consectariamente, a ampliação das atividades estatais faz crescer uma exigência por parte dos cidadãos de maior constância e estabilidade das decisões que lhes afetam. de modo que um cidadão não consegue planejar sua vida se o Estado não atuar de forma estável e consistente. Mudança e constância são, dessa forma, duas expressões que colidem no mundo pós-moderno. O princípio da proteção da confiança, imanente ao nosso sistema constitucional, visa a proteger o indivíduo contra alterações súbitas e injustas em sua esfera patrimonial e de liberdade, e deve fazer irradiar um direito de reação contra um comportamento descontínuo e contraditório do Estado." 
Assim, voltando ao exemplo de laboratório, se o caso julgado em 2009, ainda estiver em fase de admissibilidade de recurso especial, atribuir aos fatos julgados penas diversas da que consta em seu dispositivo, que não incluiu a vedação de acesso a emprego público, é violar a coisa julgada constante do acórdão condenatório (artigo $5^{\circ}, \mathrm{XXXVI}$, da CR).

Por todas essas razões nos parece inconstitucional, sem qualquer dúvida, o artigo $1^{\circ}$, letra "g", da Lei estadual $\mathrm{n}$. 15.381/10, por violação aos princípios constitucionais da segurança jurídica, proteção da confiança, coisa julgada e isonomia.

6 O DISPOSITIVO LEGAL ESTADUAL É INVÁLIDO, POIS SEU CONTEÚDO NORMATIVO CONTRASTA COM OS PRINCÍPIOS CONSTITUCIONAIS DA RAZOABILIDADE E DA AMPLA DEFESA - O COMANDO DA NORMA INSTITUI LIMITAÇÃO SUSPENSIVA DE DIREITO DE PARTICIPAR DA COISA PÚBLICA "SEM DIA DEFINIDO PARA ACABAR" E ONERA A DEFESA DOS ACUSADOS EXCESSIVAMENTE - INSTITUI A "INOMEABILIDADE OU INACESSIBILIDADE PROCESSUAL" PARA CARGOS PÚBLICOS - VIOLAÇÃO AOS ARTIGOS 5०, LIV E LV DA CONSTITUIÇÃOFEDERAL-INCONSTITUCIONALIDADE MATERIAL - DESVALIA PONTUAL DA LEI ESTADUAL NO ARTIGO 10, LETRA “G”

O dispositivo catarinense em crítica, tal qual o da lei eleitoral, criou uma "pena" sem tempo certo para expiar. Criaram essas normas indefinição quanto ao "dies ad quem" para o cumprimento da reprimenda limitadora da liberdade de se candidatar e da limitadora da liberdade de acessar cargos públicos. O legislador - eleitoral e estadual - estabeleceu uma pena que depende de circunstâncias indefinidas e incertas para acabar. Vejamos:

"Art. 1․ Fica vedada a nomeação para cargos em comissão no âmbito dos órgãos dos Poderes Executivo, $(. .$.$) às pessoas inseridas nas seguintes hipóteses:$ (...) 
g) os que forem condenados à suspensão dos direitos políticos, em decisão transitada em julgado ou proferida por órgão judicial colegiado, por ato doloso de improbidade administrativa que importe lesão ao patrimônio público e enriquecimento ilícito, desde a condenação ou o trânsito em julgado até o transcurso do prazo de 8 (oito) anos após o cumprimento da pena;"

Há um termo inicial, o da condenação colegiada, que vai até o trânsito em julgado. Isso deixa o período de expiação completamente incerto, não é possível antever, com certeza, o termo final. Concluído esse período de inacessibilidade, haverá mais o tempo do cumprimento da pena. Passado este, no dia imediato subseqüente, começara a correr mais oito anos de inacessibilidade.

Vale esta observação crítica: tendo em conta a regra estadual, não se diga que ela não constitui pena, mas "mero requisito" para provimento de cargo em comissão em SC, nos poderes constituídos estaduais. Não é possível se "importar" o inaceitável equívoco propalado pelos apologistas da lei ficha limpa eleitoral, ao dizerem que "inelegibilidade não é pena". Afirmar se inelegibilidade é ou não pena é papel da Ciência Jurídica, da Teoria do Direito. O Direito Penal, o Direito Administrativo e o Direito Eleitoral se beneficiam de seus aportes explicativos e conceituais.

A Teoria do Direito ${ }^{23}$ afirma que sanção (pena) é toda conseqüência limitadora de um direito, de uma liberdade, de um patrimônio moral ou material, decorrente de comportamento juridicizado como ilícito por norma de direito. Comportamento que resulta, para a pessoa que o realiza, a incidência de certa carga restritiva ou ablativa de liberdade em sua esfera jurídica. A sanção é o consequente do descumprimento da norma: acarreta pena a quem prática o comportamento vedado pelo direito.

23 Cf. Hans Kelsen, Teoria Geral do Direito e do Estado, São Paulo, Martins Fontes, 1990. P. 53/61. Noberto Bobbio, Teoria da Norma Jurídica, trad. Fernando Pavan e Ariani Bueno. 2 ed. São Paulo, Edipro, 2003, p. 145/176. 
A sanção pode ser de diversa natureza (privativa de liberdade, inibidora de candidaturas ou de cargos públicos, pecuniária, etc). As normas de direitos podem prevê-las através de diferentes formas legislativas (no mesmo dispositivo, comportamento vedado e sanção; ou em dispositivos constantes de leis diferentes - a norma primária [comportamento] e a secundária [sanção]). Para aplicação legítima da sanção sempre haverá um devido processo. Necessária uma autoridade competenciada para julgar a conduta e aplicar ao seu responsável as consequências sancionatórias previstas nas normas jurídicas.

Nos domínios dos direitos políticos existem comportamentos e sanções dispostas em leis diferentes, cujos atos que ensejam ilícitos são reconhecidos em um processo e perante certa autoridade - todavia a sanção é aplicada em outro processo, perante diversa autoridade. Algo demais atípico frente ao devido processo legal tradicional e ao juiz natural que conhecemos.

Exemplo significativo é a inelegibilidade decorrente de rejeição de contas públicas. O órgão constitucional que julga as contas é o Tribunal de Contas, através de processo administrativo. De suas decisões podem advir conclusões sobre comportamento que serão valorados em outro campo da jurisdição - a judicial -, e na justiça especializada - a eleitoral -, em processo judicial de registro de candidatura.

Isso se dá quando o Tribunal de Contas rejeita contas por irregularidade insanável e por decisão irrecorrível do órgão competente, o que, sob o ângulo da LC 64/90 (artigo 10, letra "g", antes da alteração da LC 135/10), será valorado na justiça eleitoral como causa potente a cercear o exercício do direito político fundamental de candidatura.

Ou seja: na justiça eleitoral se verificará se ocorreu o pressuposto de fato da norma eleitoral, que desautoriza candidatura pela ocorrência de uma ilicitude reconhecida em processo administrativo de contas, mas cujos efeitos restritivos de liberdade apenas se implementam quando houver busca de candidatura em processo judicial eleitoral. 
Ora, estaremos sim diante de sanção, medida punitiva, ablativa de direitos, sempre que um ato humano puder ser valorado como ilícito e justificante de uma limitação da liberdade. Tudo baseado em norma de direito, que limita um comportamento, estabelece consequências de sua prática e define uma autoridade para julgá-lo.

O mesmo raciocínio se aplica à compreensão da limitação de acesso aos cargos públicos como pena/sanção. E no caso de laboratório em foco: sanção que tem como pressuposto o reconhecimento de fatos que gerem condenações judiciais de improbidade colegiadas!

Voltemos ao exemplo hipotetizado. Digamos que do acórdão confirmatório da condenação resulta o seguinte conjunto sancionatório: [i] suspensão dos direitos políticos por 05 anos, [ii] proibição de contratar com o poder público por 05 anos e [iii] de receber benefícios fiscais ou creditícios por 05 anos. A esse conjunto de sanções agregarse-ia uma nova pena ex post facto e após a coisa julgada: a pena de [iv] "inacesso aos cargos públicos".

Essa última pena além de acrescer às restrições cominadas na sentença, tem um tempo maior de "aflição da liberdade" do que todas as demais, que se limitaram ao período de 05 anos. Se transitar em julgado a condenação de 2009, saberá o cidadão condenado, saberá o Judiciário e saberá a sociedade em geral, quando iniciarão as penas qüinqüenais; saberão, com certeza, o termo inicial e o termo final. $\mathrm{O}$ termo inicial é com o trânsito em julgado e o final se dará 05 anos após.

Todavia, quanto a pena ex post facto, seu termo inicial é dia 20.10.2010, tendo em conta a condenação de 2009 . Todavia, enquanto durar o processamento do recurso especial interposto pelo cidadão condenado, e este exercer "ampla defesa", pela nova regra ocorreu a seguinte mutação ilegítima: a "garantia processual individual de ampla defesa" foi transformada em uma "pena incerta", em nome 
da moralidade administrativa; há um endurecimento da "lei e da ordem", com o elastecimento sine die da pena.

Do modo como se fixou os efeitos da pena e o período de sua expiação, a ampla defesa, passou de um bem a um mal; de um bônus a um ônus; de um direito a um encargo duro e penoso.

O cidadão $X$, pela esdrúxula regra estadual, ainda que acredite em sua inocência e na possibilidade de reversão da condenação, agregará ao período expiatório que conta com 05 anos de suspensão dos direitos políticos e mais 08 anos de inacessibilidade, o imensurável tempo para esgotamento de seus recursos de defesa.

Além da incerteza do tempo de duração da pena de inacesso, se houver êxito nas pelejas recursais de X, a expiação vigorará incerta como nau sem rumo. Absolvido, jamais poderá ser compensada no plano dos seus direitos de liberdade política: essa a única certeza diante de pena sem tempo certo para durar - enquanto ela durar, nada vai compensá-lo no futuro, na esperada hipótese de absolvição em recurso!

No caso de laboratório, vejamos o absurdo da normação em abstrato: $\mathrm{X}$ tem 45 anos (em nosso suposto exemplo), sabe que ficará 13 anos fora da vida pública, mais o tempo que durar o exercício de seu direito de defesa!?!!?? Pode isso ser razoável!??!

Isso é desproporcional e abusivo não só pelo tamanho da pena, pelo tempo em que ela passou a vigorar, mais, notadamente, pela completa incerteza quanto ao tempo que vigorará seus efeitos sancionatórios, pela completa incerteza quanto ao seu termo final (que poderá durar 18 ou 20 anos ou mais, não se sabe?!)!

Além dessa normação inconstitucional, desproporcional e irrazoável sob o ângulo do princípio constitucional da proporcionalidade, outra invalidade acoima a norma da letra "g", do artigo $1^{\circ}$, da Lei estadual: a que viola o princípio da ampla defesa. Parte deste raciocínio já foi desenvolvido acima. 
E o raciocínio completo é simples: pela nova regra penal e seus efeitos incertos, além da defesa "não ser mais ampla", pois desde a condenação colegiada sem trânsito se aplica pena ao condenado, o seu exercício é um alongamento da pena, uma ampliação de seu sofrimento, o que demonstra que a norma penal anulou o valor e eficácia de uma garantia fundamental processual!

Em verdade o exercício da defesa recursal de estrito direto (ou mediante embargos infringentes, ou declaratórios, ou embargos de divergência, etc), consistirá em verdadeira "carga de ampliação do tempo de pena”, enquanto durar a busca do condenado pelo reconhecimento de sua inocência ou pela invalidade de sua condenação. E no caso hipotetizado, sendo ela conquistada, a pena já foi sofrida, expiada (caso X seja privado do cargo em comissão que ocupa), e o mal injusto decorrente de se condenar um inocente, não mais poderá ser reparado... Seu cargo, seus vencimentos, sua vida, seus projetos, sua honra, sua dignidade, jamais serão reparados!

Assim a liberdade participação em foco é solapada pela lei em comento, sem tempo certo, sem condenação definitiva e enquanto tentar o condenado exercer a garantia constitucional da ampla defesa. Isso tudo é flagrantemente inconstitucional, como anota Adriano da Costa Soares. ${ }^{24}$

E no que toca à violação ao princípio da proporcionalidade, vale ler, mais uma vez, o Ministro Celso de Mello no RE 630.147/DF ${ }^{25}$, ao analisar a lei complementar n. 135/10, lesiva

24 Vejamos: "Poderíamos didaticamente mostrar que teremos aí três inelegibilidades, que se somam: (a) a inelegibilidade desde a condenação colegiada, enquanto durar o processo; (b) a inelegibilidade durante o cumprimento da pena; e (c) mais 8 anos de inelegibilidade após o cumprimento da pena. Ou seja, enquanto o cidadão estiver recorrendo da decisão condenatória, ficará inelegível. 0 tempo do processo, no exercício do direito de defesa, passa a ser um ônus gravíssimo. Depois, se for absolvido, dane-se! Se for condenado, ficará inelegível durante o cumprimento da pena. Depois, independentemente de ter furtado uma galinha ou ter se locupletado do erário, ficará igualmente 8 anos inelegível. Somadas essas três inelegibilidades, teremos um tempo indefinido e enorme de sanção. Isso é justiçamento, vingança oficial."

25 "Como se sabe, a exigência de razoabilidade traduz limitação material à atividade do Poder Público. 
ao direito político fundamental de candidatura, por ferir a razoabilidade exigida do poder legislativo.

A pena incerta e sua transmutação do direito de defesa em encargo de ampliação da pena ditam, a mais não poder, a completa desproporcionalidade da medida legislativa levada a efeito pelo legislador catarinense, no que toca ao artigo $1^{\circ}$, letra "g" da Lei estadual n. 15.381/10.

\section{CONCLUSÃO}

O tema "ficha limpa", no âmbito do discurso jurídico, pode ser abordado entre duas perspectivas de análise: a dos moralistas e a dos constitucionalistas. ${ }^{26}$

Coloca-se em evidência, neste ponto, o tema concernente ao princípio da proporcionalidade, que se qualifica - enquanto coeficiente de aferição da razoabilidade dos atos estatais (...) - como postulado básico de contenção dos excessos do Poder Público. Essa é a razão pela qual a doutrina, após destacar a ampla incidência desse postulado sobre os múltiplos aspectos em que se desenvolve a atuação do Estado - inclusive sobre a atividade estatal de produção normativa ou, como na espécie, de resolução judicial de conflitos -, adverte que o princípio da proporcionalidade, essencial à racionalidade do Estado Democrático de Direito e imprescindível à tutela mesma das liberdades fundamentais, proíbe o excesso e veda o arbítrio do Poder, extraindo a sua justificação dogmática de diversas cláusulas constitucionais, notadamente daquela que veicula, em sua dimensão substantiva ou material, a garantia do "due process of law" (...). A validade das manifestações do Estado, portanto, analisadas estas em função de seu conteúdo intrínseco - especialmente naquelas hipóteses de imposições restritivas ou supressivas incidentes sobre determinados valores básicos (como os direitos fundamentais) - passa a depender, essencialmente, da observância de determinados requisitos que atuam como expressivas limitações materiais à ação do Poder Público. A jurisprudência constitucional do Supremo Tribunal Federal, bem por isso, tem censurado a validade jurídica de atos estatais (inclusive de atos do Poder Judiciário), que, desconsiderando as limitações que incidem sobre o poder do Estado, veiculam prescrições ou decisões que ofendem os padrões de razoabilidade e que se revelam destituídas de causa legítima, exteriorizando abusos inaceitáveis e institucionalizando agravos inúteis e nocivos aos direitos das pessoas (RTJ 160/140-141, Rel. Min. CELSO DE MELLO - RTJ 176/578-579, Rel. Min. CELSO DE MELLO - ADI 1.063/DF, Rel. Min. CELSO DE MELLO, v.g.)."

26 Ver três artigos publicados de Ruy Samuel Espíndola: (i) A Lei Ficha Limpa em revista e os empates no STF. O dilema entre o politicamente correto e o constitucionalmente sustentável. Jus Navigandi, Teresina, ano 15, n. 2711, 3 dez. 2010. Disponível em: $\leq$ http://jus.uol.com.br/revista/texto/17925>. Acesso em: 1 maio 2011; (ii) STF, insegurança jurídica e eleições em 2012: Até quando o embate entre moralistas e constitucionalistas em torno da lei ficha limpa?. Jus Navigandi, Teresina, ano 16, n. 2827, 29 mar. 2011. Disponível em: $\leq$ http://jus.uol.com.br/revista/texto/18790>. Acesso em: 2 maio 2011; (iii) Mora- 
Os moralistas seriam aqueles operadores do Direito que olhando para a nossa Constituição e para a cena política brasileira, encontram no princípio da moralidade administrativa, no princípio da probidade, na idéia de vida pregressa ilibada para candidatos, o maior valor a ser perseguido em uma eleição. Para esses operadores, tais princípios, somados ao cânone de proporcionalidade entre bens em conflito (direitos individuais x moralidade), são os principais critérios que devem balizar toda a produção das leis, especialmente uma lei que defina o processo de escolha dos candidatos, através da fixação de hipóteses de inelegibilidades ou de inacessibilidade a cargos ou empregos públicos.

Tais posturas jurídicas são alimentadas pelo sentimento geral da população (e o alimentam em retorno) de descontentamento com a classe política, que é tratada e avaliada não pela média ou excelência de seus representantes, mas sim pelos piores exemplos conhecidos midiaticamente (Paulo Maluf, Eurico Miranda, Jader Barbalho, Joaquim Roriz, etc).

Os raciocínios moralistas partem de particularidades para chegarem a generalizações nada animadoras: se alguns são tão vis e indignos, é preciso todos cuidarem de todos, pois muito mais o serão! O homem é o lobo do homem (Hobbes)! A lei eleitoral deve ser preventiva de improbidades! A presunção reinante é a de desconfiança do candidato e da não confiança na capacidade de escolha do eleitor... Por tais razões, que a justiça eleitoral, que juízes filósofos (Platão), decidam quem deve dirigir as cidades e seus governos! A vontade popular deve ser tutelada pela vontade judicial, essa última orientada pela vontade do legislador.

Os constitucionalistas, por sua vez, são aqueles operadores que veem na Constituição um limite ao exercício arbitrário de poderes públicos ou privados. Para esses a Constituição tem um sistema de direitos fundamentais que deve ser observado na feitura de leis, sem qualquer exceção para as leis eleitorais

listas versus Constitucionalistas - o caso Roriz, no STF - site Conjur e blog Adriano da Costa Soares; setembro de 2010. 
ou leis administrativas tratantes de provimento em cargo ou emprego públicos. A vontade de Constituição é o fiel da balança a regrar a vontade popular, a vontade do legislador e a vontade judicial. Para esses operadores, entre os direitos fundamentais respeitáveis em qualquer produção do Legislativo ou do Judiciário está a segurança jurídica, a não retroatividade das leis, a presunção de inocência, a razoabilidade da ação legislativa punitiva, o limite anual para incidência de leis novas que alterem o processo eleitoral. E mais: o sagrado direito de receber votos, de candidatar-se, de disputar um mandato público, de exercer um cargo público efetivo ou em comissão é tão importante quanto qualquer direito fundamental como é o de votar; é tão relevante para o regime democrático como a liberdade de ir, vir e ficar é para qualquer regime afastado da barbárie e que caminha rumo ao avanço civilizatório.

Esses operadores constitucionalistas se sustentam na razão (Voltaire), expressa na razão jurídico-constitucional, para ditarem seus comportamentos e decisões jurídicas. Para eles uma Constituição é importante também para as minorias e para conter a fúria e a paixão das maiorias, que, em dados momentos históricos, podem, sem freios constitucionais, desencadear involuções ao argumento de estatuírem progressos.

Pois há épocas em que o ânimo de fazer justiça pode levar a intoleráveis injustiças, como são os justiçamentos passionais e homicidas. Para esses operadores uma Constituição é seguro critério de julgamento em grandes causas públicas na história das nações. É o mastro de Ulysses diante do canto atraente e destrutivo das sereias. Esses homens laboram para a história, e não para o momento; eles plantam carvalhos para o amanhã e não couves para as próximas semanas (Rui Barbosa).

Esse embate entre moralistas e constitucionalistas é salutar para que descubramos, depois das lutas pelas diretas já e pelo impeachment de Collor, que a moralidade é um valor constitucional fundamental, mas não constitui um direito fundamental e não é norma superior as garantias e direitos individuais esta- 
belecidos na Constituição. Aliás, a moralidade administrativa sequer é cláusula pétrea, enquanto os direitos fundamentais o são, por obra da razão que ilumina e não da paixão que cega.

E a moralidade utilizada em alguns dos discursos midiáticos na atualidade brasileira, apesar da diferença de tempo, lugar e regime, parece ser a mesma que justificou o holocausto nazista; a prisão de Oscar Wilde; a discriminação racial que aprisionou Nelson Mandela e matou Luther King; alimentou a fúria do macarthismo no EUA e justificou atos de força e de exclusão política na era de Floriano Peixoto, Getúlio Vargas e do triunvirato militar pós 1964.

Calha ainda pontuar que a democracia não é a vacina definitiva contra a volta da ditadura nem imunidade inexpugnável contra o totalitarismo. E ditaduras e totalitarismos não morrem totalmente por que delas ou de suas cinzas emergiram democracias. Idéias democráticas assombram ditaduras (vejam os tsunamis políticos no oriente médio na crônica atual) e idéias totalitárias ou ditatoriais, convivem, cotidianamente, no seio das democracias com muita mais facilidade e sutileza (EUA, e caça ao terror; Brasil, moralidade pública superior a Constituição e seu regime de liberdades!). Muitas vezes essas idéias são ilusoriamente vendidas como democráticas... e compradas iludidamente como tais, por amplos setores da sociedade civil, imprensa, representações de classe, movimentos sociais, partidos políticos, tribunais, etc...

Isso ocorre em nações onde o debate não é verdadeiramente livre, plurilateral, franco e democrático. Onde o pluralismo de idéias é renegado em nome da unicidade dos dogmas fruto do moral e politicamente correto, a despeito do direito posto. Onde o medo de ser perseguido ou rotulado por suas idéias diferentes é moeda corrente. No Brasil não podemos deixar que tais idéias tenham vida fácil perante o Tribunal da razão e da ciência, como dissemos.

A democracia é o regime que, dialética e respeitosamente, admite o seu contrário (Norberto Bobbio). Mas é o constitucio- 
nalismo que lhe assegura a vida e impede o avanço das forças contrárias, mesmo que aclamadas por vontade popular circunstancial que agrida a perene e pétrea vontade constituinte fundacional (Vanossi).

O fiel da balança em uma democracia, que a salvaguarda da emergência de arroubos ditatoriais ou totalitários, ou melhor, de idéias provindas desses matizes, é a existência de uma Constituição democrática e efetiva (Luis Roberto Barroso). Constituição originada de uma constituinte livre, representativa e soberana, guarnecida por uma Corte Constitucional independente e ciosa de suas tarefas institucionais em um regime de direitos fundamentais e separação de poderes.

Corte Superior cujos juízes julguem, acima de qualquer expediente, com base em regras e princípios constitucionais préestabelecidos no próprio texto da Constituição. E não se fundamentem em volúveis, difusos, imprecisos e irracionais sentimentos populares vazados por setores da sociedade que nem sempre atentam para o valor de uma Lei Fundamental e seu regime de contenção dos arbítrios de toda sorte - proveiam esses abusos do Poder Estatal ou do Poder Social, ambos poderes constituídos e contidos pela Constituição democrática vigente.

No ânimo de atender a tais propósitos superiores, como integrante da ala constitucionalista do Direito, é que denunciamos, neste artigo, as inconstitucionalidades constatadas na lei catarinense n. 15.381, de 17.12.2010. Na esperança de que reine, acima das paixões, a segurança jurídica, sem a qual a democracia se desmancha e a estabilidade das instituições republicanas se desfaz.

Abstract: the essay examines constitutional aspects of the states' "clean slate" laws, which block access to public provisional office to citizens framed by the same hypotesis present in the federal Complementary Law n. 135/10. The history begins with the "clean slate" movement and its midia echos in the state and national scene. It 
elaborates on the need to preserve procedural and political fundamental rights violated by the Law n. 15.381/10, in the state of Santa Catarina. As a critical example of this law, to call the attention of federation other States or Municipalities to avoid the unconstitutionalities present in its account. It presents the Executive's initiative in the matter, the Union's competency in penal, electoral and improbity matters. It demonstrates the existing connections of the constitutional values of innocence presumption and inelegibility, onerous non retroactivity of new laws; juridical security, proportionate and extensive defense in questions concerning collegiate convictions of administrative improbity; the concept of punishment and its reflexes referring ineligibility and inaccessibility to public offices, etc. It shows clearly two theoretical lines, which clash about the matter: the moralist and the constitutionalist.

Keywords: Clean slate. State Law. Appointment to provisional public offices prohibition. Constitutionality. Exclusive Initiative. Union's competency. Political Fundamental Rights and Procedural Fundamental rights. Moralists and Constitutionalists. Democratic Institutions' Preservation.

\section{REFERÊNCIAS}

AGRA, Walber de Moura. Elementos de Direito Eleitoral. São Paulo: Saraiva, 2009.

ARAGON, Manuel. Constitución y Democracia. Madrid : Tecnos, 1990. 138 p.

ATALIBA, Geraldo. República e Constituição. São Paulo : RT, 1985. 164 p.

BARROSO, Luis Roberto. O Direito Constitucional e a Efetividade de suas Normas: Limites e Possibilidades da Constituição Brasileira. 2. ed. Rio de Janeiro : Renovar, 1993. 429 p. 
----. "A Efetividade das Normas Constitucionais Revisitada”. Revista de Direito Administrativo. Rio de Janeiro : Renovar, n. 197, jul./set. 1994.

... O Controle de Constitucionalidade no Direito Brasileiro. São Paulo: Saraiva, 2004. 299 p.

COELHO, Marcus Vinicius Furtado. Direito Eleitoral e Processo Eleitoral - Direito Eleitoral e Direito Político. 2a Ed. Rio de Janeiro: 2010.

CONCEIÇÃO, Tiago de Menezes. Direitos Políticos Fundamentais e sua suspensão por condenações criminais e por improbidade administrativa. Curitiba, Juruá, 2010.

CORDOVA JÚNIOR, Milton Retroatividade da lei da ficha limpa: O Supremo Tribunal Federal não é o limite". Jus Navigandi, Teresina, ano 15, n. 2681, 3 nov. 2010. Disponível em: 〈http://jus.uol.com.br/revista/texto/17753>. Acesso em: 3 nov. 2010

DIMOULIS, Dimitri \& MARTINS, Leonardo. Teoria Geral dos Direitos Fundamentais. 2 ed. São Paulo: Revista dos Tribunais, 2009. 304 p.

ESPÍNDOLA, Ruy Samuel. A Constituição como Garantia da Democracia: o papel dos Principios Constitucionais. Revista de Direito Constitucional e Internacional. Cadernos de Direito Constitucional e Ciência Política. São Paulo: Revista dos Tribunais/Instituto Brasileiro de Direito Constitucional, ano 11, abr./jun. 2003, n. 44.

.... "A Lei ficha limpa em revista e os empates no STF: as liberdades politicas em questão e o dilema entre o politicamente correto e o constitucionalmente sustentável." In: - George SAlomão Leite (coord.) Direitos, Deveres e Garantias Fundamentais. Bahia, Juspodium, 2011p. 781/798, p. 793/794

-..A Lei Ficha Limpa em revista e os empates no STF. O dilema entre o politicamente correto e o constitucionalmente sustentável. Jus Navigandi, Teresina, ano 15, n. 2711, 3 dez. 2010. Disponível em: Lhttp://jus.uol.com. br/revista/texto/17925>. Acesso em: 1 maio 2011;

.... STF, insegurança jurídica e eleições em 2012: Até quando o embate entre moralistas e constitucionalistas em torno da lei ficha limpa?. Jus Navigandi, Teresina, ano 16, n. 2827, 29 mar. 2011. Disponível em: 〈http://jus.uol. com.br/revista/texto/18790>. Acesso em: 2 maio 2011; (iii)

.... Moralistas versus Constitucionalistas - o caso Roriz, no STF - Conjur e Adriano da Costa Soares; setembro de 2010. 
w. Conceito de Princípios Constitucionais. 2 ed. São Paulo: Revista dos Tribunais, 2002.

BOBBIO, Norberto. A Teoria das Formas de Governo. [La teoria delle forme di governo nelle storia del pensiero politico]. Trad. Sérgio Bath, nota Nelson Saldanha, pref. Celso Lafer. 6 ed. Brasília: UnB, 1992. 179 p.

... Teoria do Ordenamento Jurídico [Teoria dell'ordinamento giuridico]. Trad. Cláudio de Cicco e Maria Celeste C. J. Santos. São Paulo/Brasília : Polis/ UnB, 1989. 184 p.

--. O Positivismo Jurídico - Lições de Filosofia do Direito. Trad. de Márcio

Pugliesi, Edson Bini e Carlos R. Rodrigues. São Paulo : Ícone, 1995. 239 p.

-. Teoria da Norma Juridica, trad. Fernando Pavan e Ariani Bueno. 2 ed. São Paulo, Edipro, 2003, p. 145/176.

... Estado, Governo e Sociedade: Para uma teoria geral da política.[Stato, Governo, Società. Per una teoria generale della política]. trad. Marco Aurélio Nogueira. 4 ed. São Paulo: Paz e Terra, 1992.

... Liberalismo e Democracia. [Liberalismo e Democrazia]. trad. Marco Aurélio Nogueira. 3 ed. São Paulo: Brasiliense, 1990. 100 p.

-.. O Futuro da Democracia: Uma Defesa das Regras do Jogo. 4a ed. Rio de Janeiro: Paz e Terra, 1989. 171 p.

... Teoria Geral da Política - a filosofia política e as lições dos clássicos. Rio de Janeiro: Campus, 2000.

CANOTILHO, José Joaquim Gomes. Direito Constitucional. 5. ed. Coimbra : Almedina, 1992. 1.214 p.

COELHO, Inocêncio Mártires. "Konrad Hesse: uma nova crença na Constituição”. Revista de Direito Público. São Paulo : RT, ano 24, n. 96, out./ dez. 1990.

KELSEN, Hans. Teoria Geral do Direito e do Estado, São Paulo, Martins Fontes, 1990. P. 53/61.

----. "La Función de la Constitución”. Apud Enrique E. Mari et alii.

Derecho y Psicoanálisis: teoría de las ficciones y función dogmática. Buenos Aires : Hachette, 1987. 168 p.

HESSE, Konrad. Escritos de Derecho Constitucional (Selección). Trad. Pedro Cruz Villalón. Madrid : Centro de Estudios Constitucionales, 1983. 112 p. 
----. Força Normativa da Constituição [Die normative Kraft der Verfassung]. Trad. Gilmar Ferreira Mendes. Porto Alegre : Fabris, 1991. 34 p.

MARMELSTEIN, George. Curso de Direitos Fundamentais. São Paulo: Atlas, 2008.

MELLO, Celso Antonio Bandeira de. Curso de Direito Administrativo, 27a ed., São Paulo: Malheiros, 2010, p. 308.

RAMOS, Elival da Silva A Inconstitucionalidade das Leis. Vício e Sanção. São Paulo: Saraiva, 1994. 255 p.

REIS, Márlon Jacinto et all (cords.). Ficha Limpa: lei complementar n. 135 de 04 de junho de 2010 interpretada pelos juristas e responsáveis pela iniciativa popular. Bauru: Edipro, 2010.

ROCHA, Carmem Lúcia Antunes . Princípios constitucionais dos servidores públicos. São Paulo: Saraiva, 1999, p. 169

SOARES, Adriano da Costa. http://adrianosoaresdacosta.blogspot.com:

VERDU, Pablo Lucas. O Sentimento Constitucional - aproximação ao estudo do sentir constitucional como modo de integração politica. Trad. Agassiz Almeida Filho. Rio de Janeiro: Forense, 2004. SC. 